\title{
Sea ice as a source of sea salt aerosol to Greenland ice cores: a model-based study
}

\author{
Rachael H. Rhodes ${ }^{1}$, Xin Yang ${ }^{2}$, Eric W. Wolff ${ }^{1}$, Joseph R. McConnell ${ }^{3}$, and Markus M. Frey ${ }^{2}$ \\ ${ }^{1}$ Department of Earth Sciences, University of Cambridge, Cambridge, CB2 3EQ, UK \\ ${ }^{2}$ British Antarctic Survey, Natural Environment Research Council, Cambridge, CB3 OET, UK \\ ${ }^{3}$ Division of Hydrologic Sciences, Desert Research Institute, Reno, NV 89512, USA \\ Correspondence to: Rachael H. Rhodes (rhr34@cam.ac.uk)
}

Received: 2 February 2017 - Discussion started: 2 March 2017

Revised: 21 June 2017 - Accepted: 4 July 2017 - Published: 7 August 2017

\begin{abstract}
Growing evidence suggests that the sea ice surface is an important source of sea salt aerosol and this has significant implications for polar climate and atmospheric chemistry. It also suggests the potential to use ice core sea salt records as proxies for past sea ice extent. To explore this possibility in the Arctic region, we use a chemical transport model to track the emission, transport, and deposition of sea salt from both the open ocean and the sea ice, allowing us to assess the relative importance of each. Our results confirm the importance of sea ice sea salt (SISS) to the winter Arctic aerosol burden. For the first time, we explicitly simulate the sea salt concentrations of Greenland snow, achieving values within a factor of two of Greenland ice core records. Our simulations suggest that SISS contributes to the winter maxima in sea salt characteristic of ice cores across Greenland. However, a north-south gradient in the contribution of SISS relative to open-ocean sea salt (OOSS) exists across Greenland, with $50 \%$ of winter sea salt being SISS at northern sites such as NEEM $\left(77^{\circ} \mathrm{N}\right)$, while only $10 \%$ of winter sea salt is SISS at southern locations such as ACT10C $\left(66^{\circ} \mathrm{N}\right)$. Our model shows some skill at reproducing the inter-annual variability in sea salt concentrations for 1991-1999, particularly at Summit where up to $62 \%$ of the variability is explained. Future work will involve constraining what is driving this inter-annual variability and operating the model under different palaeoclimatic conditions.
\end{abstract}

\section{Introduction}

Salty blowing snow lofted from the surface of sea ice may be an important source of sea salt aerosol to the polar atmosphere (Yang et al., 2008), with significant implications for climate and atmospheric chemistry. Sea salt aerosol act as cloud-condensation nuclei (O'Dowd et al., 1997) and ice nucleating particles (DeMott et al., 2016), impacting radiative forcing (Murphy et al., 1998), as well as providing surfaces for heterogeneous chemical reactions that impact the levels of key atmospheric trace gases, such as ozone (Knipping and Dabdub, 2003; Yang et al., 2010). For palaeoclimatogists, this new source of sea salt provides a mechanism that links the sea salt concentrations recorded in ice cores to sea ice extent, potentially validating the use of sea salt as a sea ice proxy (Abram et al., 2013).

Although early interpretations of ice core records assumed that sea salt was only sourced from bubble bursting at the ocean surface (e.g. Petit et al., 1999), two simple observations presented a paradoxical view: (1) seasonal sea salt maxima in most ice cores occur in winter not summer, and (2) sea salt concentrations are highest in glacial periods not interglacial periods. Given that sea ice extent is larger in winter relative to summer, and in glacials relative to interglacials, we would expect lower sea salt in winter and glacials if the open ocean was the only source of sea salt, due to the longer transport time between the open ocean and the ice sheet. Clearly that is not the case, and so, barring an unrealistic change in meteorological conditions, another source of sea salt must exist in winter (Wagenbach et al., 1998). Further evidence for an additional source comes from Antarctic snow chem- 
istry that reveals reduced $\mathrm{SO}_{4}^{2-}: \mathrm{Na}^{+}$values, relative to sea water, during winter months (Jourdain et al., 2008; Wagenbach et al., 1998). Unlike $\mathrm{NaCl}$, which contains reactive $\mathrm{Cl}^{-}$ (Keene et al., 1990; Röthlisberger et al., 2003), $\mathrm{Na}_{2} \mathrm{SO}_{4}$ is not fractionated in the atmosphere or following deposition, confirming that a source of fractionated sea salt exists in winter.

Sea ice fits the bill - its areal extent is greatest in winter, and its surface is covered by salty snow and frost flowers, which contain reduced $\mathrm{SO}_{4}^{2-}: \mathrm{Na}^{+}$sea salt (Domine et al., 2004; Yang et al., 2008). Fractionation of $\mathrm{SO}_{4}^{2-}: \mathrm{Na}^{+}$relative to sea water results from the precipitation of mirabilite salt $\left(\mathrm{Na}_{2} \mathrm{SO}_{4} \cdot 10 \mathrm{H}_{2} \mathrm{O}\right)$ from brine in the channels that dissect the sea ice (Butler and Kennedy, 2015), and from sea water that floods or inundates slabs of sea ice (Massom et al., 2001). Frost flowers are now thought to make a relatively small contribution to the sea salt aerosol load sourced from the sea ice surface because of their high mechanical strength (Obbard et al., 2009), subsequent lack of observed aerosol production (Yang et al., 2017), even under high wind speeds (Roscoe et al., 2011), and limited spatial and temporal range (Kaleschke et al., 2004; Perovich and Richter-Menge, 1994).

The model of Yang et al. (2008) proposes that the principal source of sea salt from the sea ice surface is the entrainment of salty snow particles by high winds during blowing snow events, known to occur in the Antarctic (Mann et al., 2000; Nishimura and Nemoto, 2005) and Arctic (Savelyev et al., 2006). The air within the blowing snow layer is saturated for water vapour, but the relative humidity reduces with height (Mann et al., 2000), allowing the water content of snow particles to sublime, generating sea salt aerosol (Déry and Yau, 2001).

The sea ice source of sea salt aerosol appears to be critical for polar atmospheric chemistry. Domine et al. (2004) suggest that the salty snow on sea ice is an important source of $\mathrm{Br}^{-}$ions that contribute to the ozone depletion events observed over the sea ice in the spring. This idea is supported by evidence of air masses associated with ozone depletion originating from the sea ice zone (Jones et al., 2009). Yang et al. (2010) used a modelling approach to demonstrate that blowing snow provided the additional sea salt aerosol required to sustain the high levels of $\mathrm{BrO}$ responsible for the destruction of ozone in the polar regions.

To explore the implications of this additional source of sea salt aerosol for sea ice proxy development, a chemical transport model can be used to represent emission, transport and deposition of sea salt aerosol. Using this approach, Levine et al. (2014) found that sea-ice-sourced sea salt made a significant contribution to the winter sea salt aerosol budget at various Antarctic locations, and that this improved the modeldata match with aerosol observations. Recently, these results have been replicated (Legrand et al., 2016) and confirmed using a different model (GEOS-Chem) with similar parameterizations of sea salt emissions (Huang and Jaeglé, 2017).
Table 1. Parameters chosen for p-TOMCAT base simulation 19912006.

\begin{tabular}{lll}
\hline Parameter & Value/setting used & Reference \\
\hline OOSS emissions & $\begin{array}{l}\text { OOSS emission by bub- } \\
\text { ble bursting + SST de- } \\
\text { pendence }\end{array}$ & $\begin{array}{l}\text { Gong et al. (2003) } \\
+ \text { Jaeglé et al. } \\
(2011)\end{array}$ \\
\hline SISS emissions & $\begin{array}{l}\text { SISS emission via blow- } \\
\text { ing snow }\end{array}$ & Yang et al. (2008) \\
Snow salinity & $\begin{array}{l}\text { mean 0.6 psu (Arctic) } \\
\text { Snow age }\end{array}$ & $\begin{array}{l}\text { 24h (Arctic) } \\
\text { Multi-year sea ice }\end{array}$ \\
& $\begin{array}{l}\text { SISS emissions are re- } \\
\text { duced by 50\% relative }\end{array}$ \\
& to first-year sea ice & \\
\hline
\end{tabular}

Huang and Jaeglé (2017) also argue for the importance of the blowing snow sea salt source in the Arctic region.

Here we investigate sea salt in the Arctic region in greater depth, with a particular emphasis on how sea-ice-sourced sea salt may impact the sea salt budget of Greenland ice cores. Doing so should help us to decipher whether Greenland ice core sea salt records have any potential to record past sea ice changes in the Arctic.

\section{Methods}

In this study, our base simulation, run from 1991 to 2006, is tuned (Table 1) to sea salt aerosol observations from across the Arctic. The influence of various tuning parameters is tested in sensitivity tests (Sect. 3). The performance of our chemical transport model at simulating the concentration of sea salt deposited in snow on the Greenland ice sheet is evaluated by comparing simulations of monthly mean sea salt concentrations in snowfall to values in Greenland ice cores (Sect. 4).

\subsection{Arctic sea salt aerosol data}

We use sea salt aerosol data from five Arctic locations as targets for tuning our chemical transport model (Fig. 1). The five Arctic aerosol sites are Barrow in Alaska (Quinn et al., 2002), Alert in Canada (Barrie, 1995), Zeppelin Station on Svalbard, Villum Station in northern Greenland, and Summit on the Greenland ice sheet (see the Supplement for detail on Summit aerosol data). For additional assessment of the model's skill at representing sea salt aerosol in the atmosphere, we also compare model output to measurements from five low/mid-latitude aerosol sampling stations (Fig. S1 in the Supplement) in the AEROCE-SEAREX network (Savoie et al., 2002). The age range of the aerosol data from each site is displayed in black on any figure where the data are included. Aerosol data are compared to model output for 0.1$5 \mu \mathrm{m}$ dry particle radius $\left(r_{\text {dry }}\right)$. 


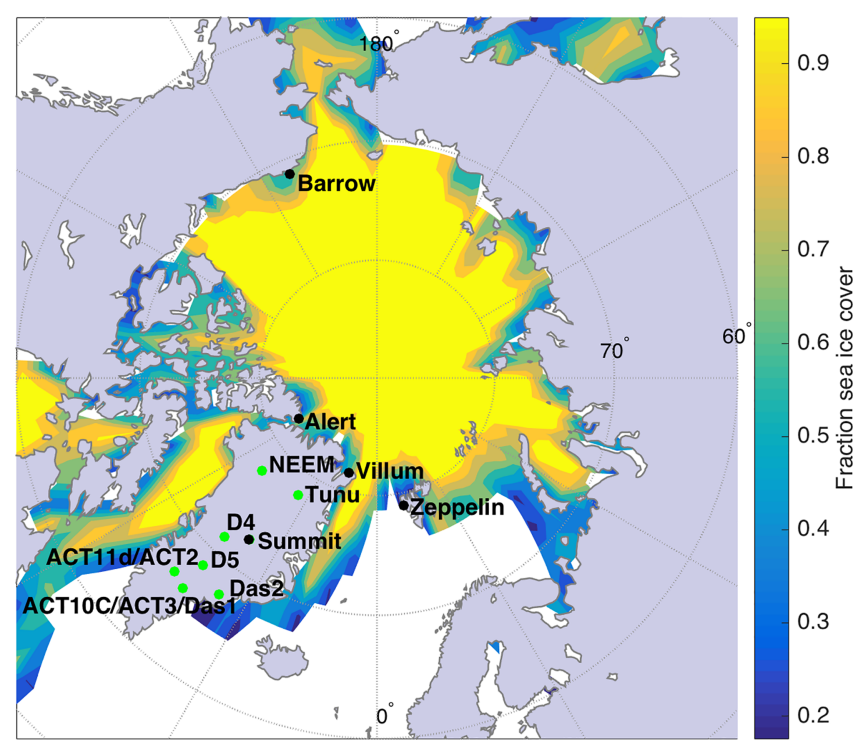

Figure 1. Map of the Arctic region showing locations of aerosol sampling stations (black circles) and ice cores (green circles) used in this study. Contoured shading is mean February fractional sea ice coverage for 1991-1999, as prescribed in p-TOMCAT.

\subsection{Greenland ice core sea salt records}

Greenland ice core Na records (Fig. 1, Table 2) from 1991 to 1999 are compared with simulations for the same time interval. The simulations include model output from the entire $r_{\text {dry }}$ range $(0.1$ to $10 \mu \mathrm{m})$.

All the ice cores were analysed using the continuous melter system at the Desert Research Institute, Reno, USA (McConnell et al., 2002). Na was measured by highresolution inductively coupled plasma mass spectrometry (HR-ICP-MS) with an estimated reproducibility of $<2 \mathrm{ppb}$ $(2 \sigma)$. The records are dated by annual layer counting of multiple chemical species that typically show different timings of seasonal maxima - e.g. sea salt, mineral dust, and biomass burning products (Sigl et al., 2013). All the cores, except Tunu13, have accumulation rates $>200 \mathrm{~kg} \mathrm{~m}^{-2} \mathrm{yr}^{-1}$ (Table 2), providing monthly resolution records with age uncertainty of $<0.25$ years. Uncertainty on dating at the subannual scale originates from the uncertainty in the absolute timing of each seasonal marker and the assumption of a constant annual snow accumulation rate.

\subsection{Chemical transport model}

\subsubsection{Model description}

We use a simplified version of the Cambridge parallelized Tropospheric Offline Model of Chemistry and Transport (pTOMCAT) to simulate the emission, transport and deposition of sea salt aerosol (Fig. 2), following the work of Levine et al. (2014). p-TOMCAT is a 3-D global model with a spatial res- olution of $2.8^{\circ} \times 2.8^{\circ}$ across 31 vertical sigma-pressure levels. Here we only describe changes to the model parameterization implemented since the study of Levine et al. (2014).

In this study, we drive p-TOMCAT with 6-hourly temperature, wind and humidity fields from the European Centre for Medium-Range Weather Service Forecasts (ECMWF) ERA-Interim reanalysis data set (Dee et al., 2011) whereas Levine et al. (2014) used ECMWF operational data. The significant precipitation bias of p-TOMCAT (Giannakopoulos et al., 2004) is remedied by applying a correction to force the simulated precipitation values towards Global Precipitation Climatology Project (GPCP) observations (Adler et al., 2003), following Legrand et al. (2016). The corrected precipitation fields are used in wet deposition calculations (Sect. 2.3.3).

Sea salt aerosol particles are traced from emission to deposition in 21 size bins ranging from 0.1 to $10 \mu \mathrm{m} r_{\mathrm{dry}}$. The ambient radius $\left(r_{\text {wet }}\right)$ of each particle may change each time step according to relative humidity and temperature. Particles sourced from the open-ocean and the sea ice surface, which we will refer to as open-ocean sea salt (OOSS) and sea ice sea salt (SISS) respectively, are treated separately, giving a total of 42 tracers. In p-TOMCAT, sea salt (SISS or OOSS) is assumed to be pure $\mathrm{NaCl}$.

\subsubsection{Sea salt emissions}

Parameterization of OOSS emissions follows Gong (2003) and is based on the classic Monahan (1986) model of aerosol production via bubble bursting (Fig. 2). Gong et al.'s scheme is modified to account for a dependence of sea salt aerosol production on sea surface temperature (SST) (Eq. 4 of Jaeglé et al., 2011).

Parameterization of SISS emissions follows Yang et al. (2008) (Eqs. 1-8) and this requires salinity and particle size distributions of snow particles entrained from the sea ice surface during blowing snow events to be defined (Fig. 2). We use new observations made during a wintertime cruise of the RV Polarstern (June-August 2013) in the Weddell Sea, Antarctica. These measurements were conducted in the framework of the BLOWSEA project led by the British Antarctic Survey (https://doi.org/10.5285/c0261633fd14-4d45-a58d-72998816c4cd; Frey, 2017). The salinity distribution only includes measurements from the top $10 \mathrm{~cm}$ of the snow pack, as this snow is the most likely to be lofted up. Any individual salinity measurements $>10$ psu are excluded from the distribution. The mean salinity is $0.30 \mathrm{psu}$, which is 14-fold lower than that of the salinity distribution used by Levine et al. (2014) (4.25 psu) for snow on Antarctic sea ice. In our base simulation, this salinity distribution is doubled for snow on Arctic sea ice (Table 1, Sect. 3.3.1). The probability density function that defines the size distribution of suspended particles in blowing snow events (Yang et al., 2008, their Eq. 6) has a snow particle radius of $70.3 \mu \mathrm{m}$ and shape parameter $(\alpha)$ value of 2. p-TOMCAT does not simu- 
Table 2. Key characteristics of Greenland ice core records used.

\begin{tabular}{|c|c|c|c|c|c|c|}
\hline Ice core & Location & $\begin{array}{r}\text { Elevation } \\
(\mathrm{m})\end{array}$ & $\begin{array}{l}\text { Accumulation rate } \\
\quad\left(\mathrm{kg} \mathrm{m}^{-2} \mathrm{yr}^{-1}\right)\end{array}$ & $\begin{array}{r}\text { Distance to coast } \\
(\mathrm{km})\end{array}$ & $\begin{array}{r}\text { Record end } \\
\text { (year) }\end{array}$ & Reference \\
\hline Tunu13 & $78^{\circ} 2.09^{\prime} \mathrm{N}, 33^{\circ} 52.80^{\prime} \mathrm{W}$ & 2105 & 112 & 300 & 2011 & Maselli et al. (2017) \\
\hline NEEM-2011-S1 ${ }^{\mathrm{b}}$ & $77^{\circ} 26.93^{\prime} \mathrm{N}, 51^{\circ} 03.37^{\prime} \mathrm{W}$ & 2454 & 203 & 280 & 1997.5 & Sigl et al. (2013) \\
\hline NEEM-2008-S $3^{b}$ & $77^{\circ} 26.93^{\prime} \mathrm{N}, 51^{\circ} 03.37^{\prime} \mathrm{W}$ & 2454 & 203 & 280 & 2001 & \\
\hline NEEM-2010-20m ${ }^{b}$ & $77^{\circ} 26.93^{\prime} \mathrm{N}, 51^{\circ} 03.37^{\prime} \mathrm{W}$ & 2454 & 203 & 280 & 2008 & \\
\hline Summit2010 (a.k.a. Zoe2) & $72^{\circ} 36.0^{\prime} \mathrm{N}, 38^{\circ} 18.0^{\prime} \mathrm{W}$ & 3258 & 222 & 530 & 2010 & Maselli et al. (2017) \\
\hline 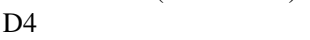 & $71^{\circ} 24.0^{\prime} \mathrm{N}, 43^{\circ} 54.0^{\prime} \mathrm{W}$ & 2730 & 414 & 320 & 2003 & Banta et al. (2008) \\
\hline D5 & $68^{\circ} 30.0^{\prime} \mathrm{N}, 42^{\circ} 54.0^{\prime} \mathrm{W}$ & 2468 & 373 & 350 & 1998 & Banta et al. (2008) \\
\hline Das2 & $67^{\circ} 30.0^{\prime} \mathrm{N}, 36^{\circ} 06.0^{\prime} \mathrm{W}$ & 2936 & 833 & 110 & 2003 & Banta et al. (2008) \\
\hline $\operatorname{Das} 1^{\mathrm{c}}$ & $66^{\circ} 00.0^{\prime} \mathrm{N}, 44^{\circ} 00.0^{\prime} \mathrm{W}$ & 2497 & 600 & 200 & 2003 & Banta et al. (2008) \\
\hline $\mathrm{ACT} 10 \mathrm{C}^{\mathrm{c}}$ & $65^{\circ} 59.93^{\prime} \mathrm{N}, 42^{\circ} 47.0^{\prime} \mathrm{W}$ & 2299 & 809 & 200 & 2009.5 & \\
\hline $\mathrm{ACT}^{\mathrm{c}}$ & $66^{\circ} 00.0^{\prime} \mathrm{N}, 43^{\circ} 36.0^{\prime} \mathrm{W}$ & 2508 & 658 & 200 & 2005 & \\
\hline $\mathrm{ACT} 2^{\mathrm{d}}$ & $66^{\circ} 00.0^{\prime} \mathrm{N}, 45^{\circ} 12.0^{\prime} \mathrm{W}$ & 2419 & 372 & 240 & 2004 & Banta et al. (2008) \\
\hline ACT $11 d^{d}$ & $66^{\circ} 28.8^{\prime} \mathrm{N}, 46^{\circ} 18.6^{\prime} \mathrm{W}$ & 2296 & 339 & 240 & 2011 & \\
\hline
\end{tabular}

${ }^{a}$ Water-equivalent accumulation rate. ${ }^{b}$ Same grid square in p-TOMCAT. ${ }^{c}$ Same grid square in p-TOMCAT. ${ }^{d}$ Same grid square in p-TOMCAT

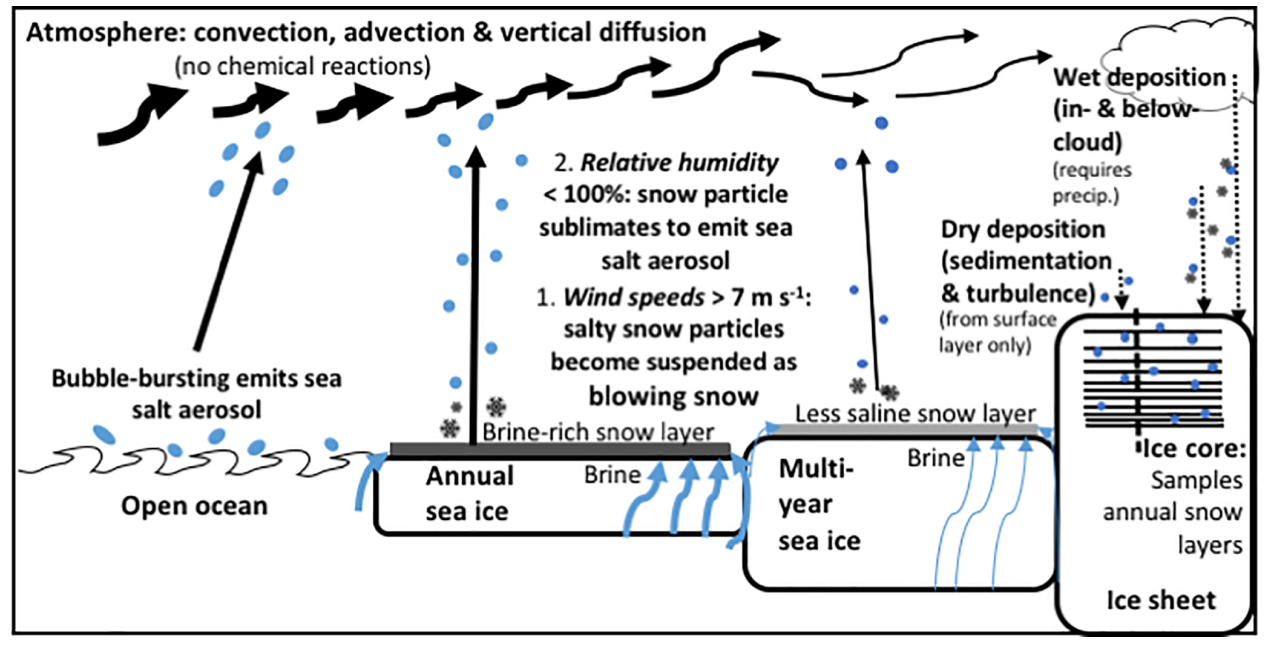

Figure 2. Schematic of processes parameterized by p-TOMCAT that influence sea salt concentrations in the atmosphere and ice cores.

late snow particles splitting into multiple individual sea salt aerosol (see Huang and Jaeglé, 2017).

The parameterization of SISS production by Yang et al. (2008) includes a parameter called snow age $(t$ in Yang et al.'s Eq. 5), adopted from Box et al. (2004). A higher value of snow age decreases SISS emissions, loosely representing how sintered snow flakes are likely more difficult to mobilize than fresh ones. Levine et al. (2014) found that the precipitation frequency and intensity within p-TOMCAT was not suitable for defining a transient snow age so a constant value of 5 days was used. When combined with our reduced snow salinity, this high snow age, which reduces the amount of blowing snow by almost a factor of 4 compared to a snow age of zero, resulted in extremely low SISS emissions. Since it is not clear that the parameterization of snow age has any firm basis for the very cold conditions encountered in the Arctic, we used snow age as a crude tuning device, and (as discussed in Sect. 3.3.3) adopted a value of $24 \mathrm{~h}$ for our base simulation (Table 1).

Finally, the "gustiness factor" used by Levine et al. (2014) to increase the 6-hourly wind speeds used for sea salt aerosol emissions has been removed because it is specific to a different chemical transport model (Gong et al., 2002). We have not replaced this value so peak sea salt emissions may be underestimated due to the 6-hourly averaging of wind speeds. Sensitivity testing indicates that using a "gustiness factor" decreases the correspondence between model results and aerosol data at Arctic sites (Fig. S4).

\subsubsection{Sea salt deposition}

The deposition of OOSS and SISS in p-TOMCAT follows the parameterizations of Reader and MacFarlane (2003) (see also Levine et al., 2014, Eqs. 1-9). Wet deposition via nucleation and collision are both parameterized by exponential de- 
cay. Collision scavenging is determined by the collision scavenging parameter $\left(\alpha_{\mathrm{C}}\right.$, units: $\left.\mathrm{m}^{2} \mathrm{~kg}^{-1}\right)$ that varies with $r_{\text {wet }}$ and by the rate of precipitation occurring at the same atmospheric level and all levels above $\left(\mathrm{PC}_{\mathrm{L}}\right.$, units: $\left.\mathrm{kg} \mathrm{m}^{-2} \mathrm{~s}^{-1}\right)$. Nucleation scavenging is dependent on the nucleation scavenging parameter $\left(\alpha_{\mathrm{N}}\right.$, units of $\left.\mathrm{m}^{2} \mathrm{~kg}^{-1}\right)$ and the rate of precipitation occurring only within the same atmospheric level $\left(\mathrm{PN}_{\mathrm{L}}\right.$, units: $\left.\mathrm{kg} \mathrm{m}^{-2} \mathrm{~s}^{-1}\right)$. Dry deposition only occurs in the surface layer of the model, which has a half-height ( $h$, units: $\mathrm{m}$ ) that varies between 23 and $36 \mathrm{~m}$, depending on the geographic location and season. Calculation of the dry deposition velocity ( $v_{\mathrm{d}}$, units: $\mathrm{m} \mathrm{s}^{-1}$ ) accounts for the processes of sedimentation and turbulence.

In order to compare our model simulations of Arctic sea salt aerosol to Greenland ice core Na concentrations, we calculate how much OOSS and SISS is deposited at each time step, in addition to keeping track of the mass remaining in the atmosphere ( $M$, units: $\mathrm{kg})$. The mass of sea salt in each particle size bin $\left(r_{\text {dry }}\right)$ removed from each sigma-pressure level (L) in the atmosphere at each time step $(\Delta t=1800 \mathrm{~s})$ via wet (MWD, units: $\mathrm{kg}$ ) and dry deposition (MDD, units: $\mathrm{kg}$ ) is calculated by Eqs. (1) and (2) respectively:

$$
\begin{aligned}
& \mathrm{MWD}_{\mathrm{L}, r_{\text {dry }}, t}=\mathrm{M}_{\mathrm{L}, r_{\text {dry }}, t-\Delta t} \times e^{-\left(\alpha_{\mathrm{C}} \mathrm{PC}_{\mathrm{L}}+\alpha_{\mathrm{N}} \mathrm{PN}_{\mathrm{L}}\right) \Delta t}, \\
& \mathrm{MDD}_{r_{\text {dry }}, t}=\mathrm{M}_{r_{\text {dry }}, t-\Delta t} \times v_{\mathrm{d}} \times \Delta t / h, \\
& \mathrm{SS}_{\text {mass }, r_{\text {dry }}, t}=\mathrm{MWD}_{\mathrm{L}, r_{\text {dry }}, t}+\mathrm{MDD}_{r_{\text {dry }}, t}, \\
& \mathrm{Na}_{\text {mass }, r_{\text {dry }}, t}=\mathrm{SS}_{\text {mass }, r_{\text {dry }}, t} \times 0.3906, \\
& \mathrm{Na}_{\text {flux }}=\left(\mathrm{Na}_{\text {mass }} \times 1 e^{9}\right) / a \times 12, \\
& {[\mathrm{Na}]_{\text {snow }}=\mathrm{Na}_{\text {flux }} / A .}
\end{aligned}
$$

After converting the mass of deposited sea salt $\left(\mathrm{SS}_{\mathrm{mass}}\right.$, Eq. 3) to mass of $\mathrm{Na}$ (Eq. 4), the flux of $\mathrm{Na}\left(\mathrm{Na}_{\text {flux }}\right.$, units: $\mu \mathrm{g} \mathrm{m}^{-2} \mathrm{yr}^{-1}$ ) from the atmosphere to the ice sheet is calculated via Eq. (5), where $a$ is the area of grid box (units: $\mathrm{m}^{2}$ ) and $\mathrm{Na}_{\text {mass }}$ is a monthly total $\mathrm{Na}$ mass deposited (units: $\mathrm{kg}) . \mathrm{Na}_{\mathrm{flux}}$ is then divided by the snow accumulation rate $(A$, units: $\mathrm{kg}$ water $\mathrm{m}^{-2} \mathrm{yr}^{-1}$ ), which is the sum of precipitation at all atmospheric levels in p-TOMCAT, to give the simulated concentration of sea salt Na (either OOSS or SISS) in the snow (Eq. 6, [Na $]_{\text {snow }}$, units: $\mu \mathrm{g} \mathrm{kg}^{-1}$ or parts per billion (ppb)).

\section{Tuning p-TOMCAT}

\subsection{Timing of sea salt deposition}

Wet and dry deposition of sea salt in p-TOMCAT now takes place immediately after emissions, before any atmospheric mixing, which was not the case for the studies of Levine et al. (2014) and Legrand et al. (2016). This change was implemented to prevent large-diameter aerosol, which can have atmospheric lifetimes (with respect to dry deposition) that are shorter than the model's dynamical time step $(30 \mathrm{~min})$, from leaving the surface layer. This modification caused only a modest difference in sea salt loading of the surface layer of the atmosphere in p-TOMCAT, particularly inland (Fig. S2A). However, the simulated ice core Na concentrations ([Na]) decreased substantially, sometimes by more than two thirds (Fig. S2B), because large aerosol were rapidly removed from the atmosphere after emission (Fig. S3), before they could be advected up above the surface layer.

\subsection{Open ocean emissions}

Comparison of the monthly aerosol sea salt data from the five $\mathrm{mid} / \mathrm{low}$-latitude aerosol coastal sampling sites with the pTOMCAT base simulation informs us about how well OOSS emissions are represented in the model. Overall, p-TOMCAT performs well, achieving normalized root mean squared differences (NRMSD) of between 28 and $62 \%$ at the five sites (Fig. S1). Aerosol [Na] values tend to be underestimated by $\mathrm{p}$-TOMCAT, but usually the $1 \sigma$ inter-annual variability ranges of model and data overlap with each other. The tendency towards underestimation could be due to (1) OOSS emissions may be underestimated due to 6-hourly averaging of wind speeds and (2) depositing sea salt directly after emissions causes a strong depletion of large sea salt aerosol particles ( $>4 \mu \mathrm{m} r_{\text {dry }}$ ) in the surface layer relative to the size spectrum of particles emitted (Fig. S3) - this deposition scheme may be too aggressive.

At the Arctic aerosol sampling sites, except Zeppelin, simulated OOSS Na concentrations fall within the range of observations in the summer months (Fig. 3). This suggests that p-TOMCAT captures OOSS in the Arctic well, assuming the model is accurate in simulating a minimal SISS contribution to the summer sea salt budget. Sensitivity tests show that the SST dependent OOSS emissions (Jaeglé et al., 2011) we use here produces the best match between aerosol observations and model simulations at Arctic sites. A small improvement may be gained in future work using p-TOMCAT by adopting the further modifications recently published by Haung and Jaeglé (2017), which restrict OOSS emissions at SSTs $<5^{\circ} \mathrm{C}$ and in high-latitude grid squares with $<50 \%$ water coverage (Fig. S4).

\subsection{Sea ice surface emissions}

Results from our base simulation (Table 1) indicate that simulated OOSS alone cannot reproduce the seasonal variability of aerosol Na observations at Arctic aerosol sites (Fig. 3). In the winter months, the simulated OOSS Na profiles show a deficit of Na relative to the observations. This is consistent with the idea that blowing snow from the sea ice surface (SISS) is an important source of sea salt to the Arctic and its inclusion in model studies is essential to replicate Arctic aerosol observations.

We now consider the influence of some of the various parameters that can influence SISS emissions via the blowing 

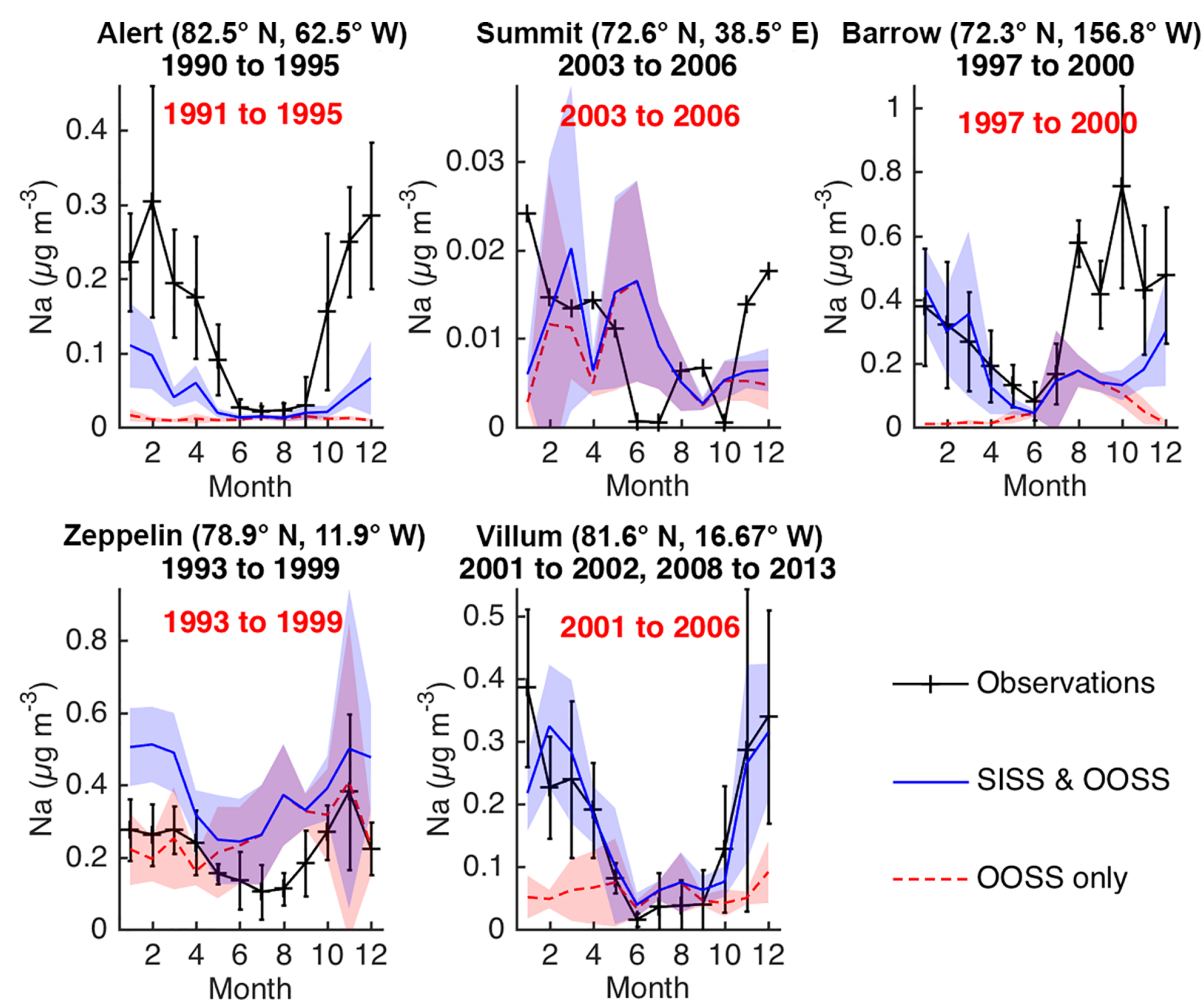

$\longrightarrow$ Observations

_ SISS \& OOSS

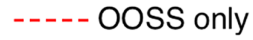

Figure 3. Sea salt Na aerosol concentrations at Arctic locations simulated by p-TOMCAT base simulation (Table 1) compared to observations. Date range of aerosol observations is displayed in black and date range of p-TOMCAT simulations is displayed in red on each subplot. Observations and model results are mean monthly values with uncertainty bars or shaded bounds representing $\pm 1 \sigma$ of the inter-annual variability. The Summit observations are not plotted with uncertainty bars because temporal coverage of data set is too poor (Supplement). p-TOMCAT aerosol size bins $1-18\left(0.1-5 \mu \mathrm{m} r_{\text {dry }}\right)$ are included.

snow mechanism. p-TOMCAT was run repeatedly for the year 1997, changing individual parameters to assess the effect (Fig. 4) relative to our base simulation (Table 1).

\subsubsection{Snow salinity}

To first order, we might expect Arctic snow on sea ice of a given age to be more saline than Antarctic snow, because less precipitation occurs in the Arctic sea ice zone relative to the Antarctic sea ice zone (Yang et al., 2010). We double the observed salinity distribution from the Weddell Sea, Antarctica, for snow on Arctic sea ice in our base simulation (mean salinity is $0.6 \mathrm{psu}$, Table 1 , while the median value is $0.12 \mathrm{psu}$ ). We chose a 2 -fold increase because the precipitation rate over sea ice simulated by p-TOMCAT is $50 \%$ higher over Antarctic sea ice relative to Arctic sea ice.

However, some estimates have put Arctic snow salinity as 3 -fold higher than Antarctic snow salinity (Yang et al., 2010). We tested the effect of using a higher snow salinity (3-fold Antarctic salinity $=0.9$ psu) (Fig. $4 \mathrm{~d}$ ) and found that this produced a small reduction in the overall model-observations agreement across the five sites relative to our base simulation (Fig. 4a), although Summit, Barrow, and Villum all showed a reduced model-data difference $(\Delta \mathrm{Na})$. There are very few measurements of snow salinity on sea ice in the Arctic to compare to, and values are likely to vary with season and location. Mundy et al. (2005) reported a mean salinity of $0.11 \pm 0.25$ psu for the surface snow in the central Canadian Arctic, 6-fold lower than used in our base simulation, but close to our median value.

\subsubsection{Multi-year sea ice}

In the Arctic, around half of the winter sea ice is multi-year ice. We know that the salinity, or brine content, of sea ice decreases as brine is progressively expelled through brine rejection (Cox and Weeks, 1974). Therefore, it is likely that the brine supply to the sea ice surface reduces with time, thereby reducing the salinity of the surface snow. Furthermore, multiyear sea ice is generally thicker and more stable than firstyear ice, which limits flooding and inundation by sea water at cracks and leads (Massom et al., 2001), also likely reducing snow salinity as the salt supply is replenished less often. We have limited direct evidence from snow sampling (Krnavek et al., 2012) but enough to deem that first-year sea ice will harbour more saline snow than multi-year sea ice, therefore producing blowing snow particles with a higher Na concentration. 

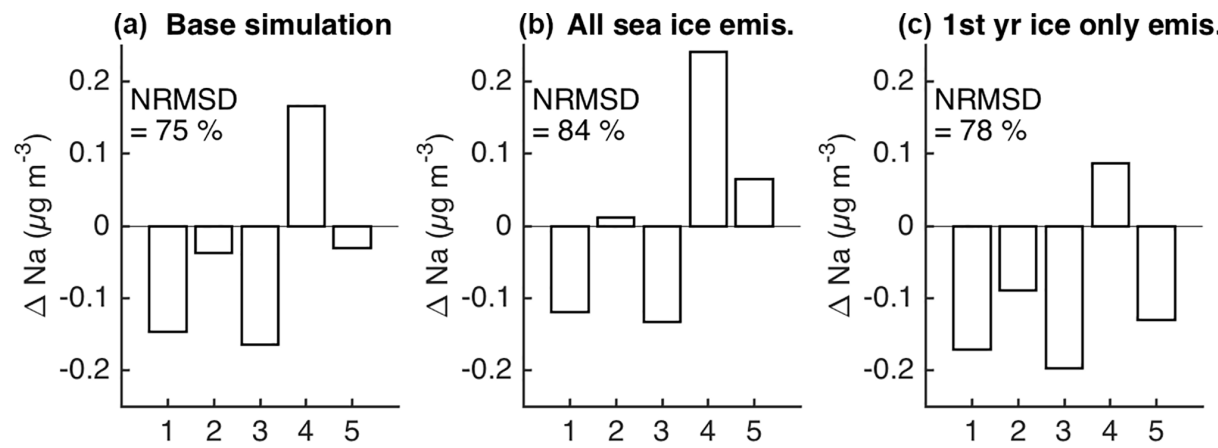

(d) 0.9 psu snow salinity

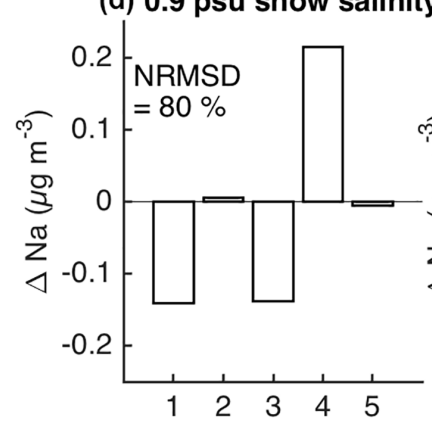

(e) $12 \mathrm{~h}$ snow age

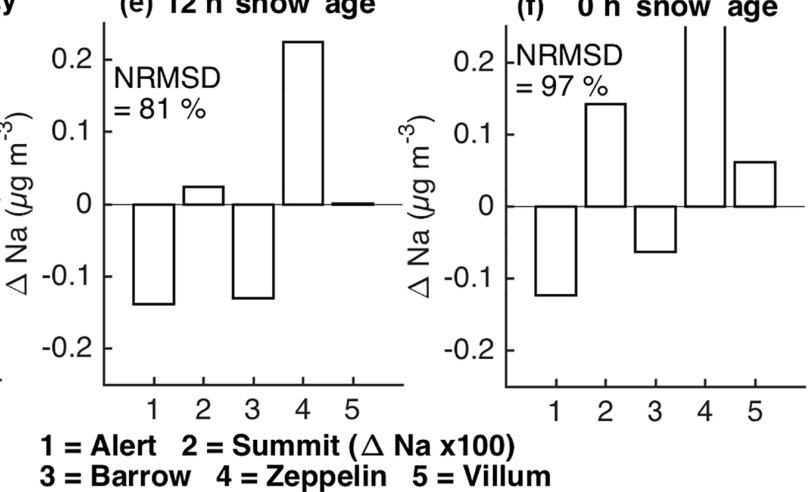

Figure 4. Sensitivity of p-TOMCAT Na aerosol simulations for 1997 at five Arctic locations to parameters associated with SISS emissions via blowing snow. Each panel (a-e) displays the mean difference between monthly (not including July-September) model results and observations $(\triangle \mathrm{Na})$ for each site. Dates of observations are shown in black text in Fig. 3. Positive (negative) values indicate that p-TOMCAT overestimates (underestimates) aerosol Na concentration. The normalized root mean square difference (NRMSD) between model simulations and aerosol data is calculated for each of the five sites and the mean NRMSD across all five sites is displayed on each subplot. Plots of simulated monthly Na concentration at each site, under each scenario, are displayed in Fig. S5. See Table 1 for base simulation parameters.

In p-TOMCAT, Arctic sea ice in each grid box is classed as multi-year ice if it was present in the preceding September. As we have little field evidence to indicate how snow salinity evolves with time or ice thickness, we crudely reduce the SISS emissions of regions covered by multi-year ice instead of explicitly altering the salinity of blowing snow particles above multi-year ice. In our base simulation, multi-year sea ice contributes $50 \%$ of the SISS emissions of first-year sea ice. We note that this does not necessarily reflect the impact that halving snow salinity would have on SISS emissions. We tested two alternative scenarios: (1) both first-year and multiyear sea ice contribute equally to SISS emissions (Fig. 4b), and (2) only first-year sea ice contributes SISS emissions (Fig. 4c). For 1997, the total SISS emissions in the Arctic region in our base simulation was $2.66 \mathrm{Tg} \mathrm{Na}$, and in each experiment, it was 3.57 and $1.67 \mathrm{Tg} \mathrm{Na}$ respectively. The impact on simulated Na concentrations at Arctic aerosol monitoring sites was significant at all five Arctic sites (Fig. 4a-c). At Zeppelin, OOSS is overestimated by the model so $\Delta \mathrm{Na}$ is always positive regardless of the multi-year ice option. p-TOMCAT simulates too much $\mathrm{Na}$ (positive $\Delta \mathrm{Na}$ ) at Villum in N. Greenland when all sea ice contributes the same SISS emissions and not enough $\mathrm{Na}$ (negative $\Delta \mathrm{Na}$ ) when only first-year ice contributes. The $\Delta \mathrm{Na}$ value is lowest for the base simulation when multi-year ice contributes $50 \%$ of SISS emissions. At Alert, $\Delta \mathrm{Na}$ is negative in all three cases as not enough SISS reaches the site in winter (Fig. S5).

Our base simulation, in which multi-year sea ice contributes $50 \%$ of the SISS emissions of first-year sea ice, produces the lowest NRMSD averaged across the Arctic sites. Although this option does not produce the best correspondence between model and observations at every Arctic aerosol site, it is important to make some distinction between the SISS emissions of first- and multi-year sea ice given the likelihood of snow salinity difference. However, we do note that the difference between the simulated seasonal aerosol $[\mathrm{Na}]$ at the five sites under the three different multi-year sea ice options is relatively small at Summit (Fig. S4) and therefore this choice does not greatly impact the sea salt budget of the atmosphere above Greenland.

\subsubsection{Snow age}

Higher values of snow age result in reduced SISS emissions. We tested the impact of decreasing the snow age in the Arctic from $24 \mathrm{~h}$ in our base simulation (Fig. $4 \mathrm{a}$ ) to $12 \mathrm{~h}$ (Fig. $4 \mathrm{e}$ ) or 
to zero (Fig. 4f) for 1997. For some sites, such as Barrow and Alert, $\triangle \mathrm{Na}$ was reduced with a snow age of 12 or $0 \mathrm{~h}$ (Fig. 4e and f compared to Fig. 4a). The model-observations match across all the Arctic sites was reduced for both the $12 \mathrm{~h}$ and zero snow age (NRMSD increased). If we exclude Zeppelin from the calculation for $12 \mathrm{~h}$ snow age, the NRMSD is similar that achieved for the base simulation using a snow age of $24 \mathrm{~h}$. The maximum change in monthly [Na] caused by setting the snow age to zero is a $70 \%$ increase in [Na] at Barrow in January (Fig. S5).

\subsection{Comparison between p-TOMCAT and GEOS-Chem}

The performance of p-TOMCAT can be further evaluated by comparing the simulation Arctic sea salt aerosol budget to that reported by Huang and Jaeglé (2017), who use the GEOS-Chem model (Table 3). In order to make a direct comparison with their reported values, Table 3 reports values for 2005 only, which refer to sea salt aerosol, not just $\mathrm{Na}$, and are for the Arctic region only (note: lifetime in the Arctic region $\neq$ lifetime in the atmosphere).

For OOSS, the two models are broadly similar, with a tendency towards a higher burden, surface concentration, and Arctic lifetime in GEOS-Chem. For SISS, the emission rates are different between p-TOMCAT and GEOS-Chem. p-TOMCAT emits $\sim 5 \times$ more SISS in the $0.57 \mu \mathrm{m}<r_{\text {dry }} \leq 4.5 \mu \mathrm{m}$ range than GEOS-Chem, while GEOS-Chem emits more than double the SISS of $\mathrm{p}$ TOMCAT in the smaller particle size range. This difference is due to the tuning introduced by Huang and Jaeglé (2017) that causes each snow particle to produce five sea salt aerosol (whereas in p-TOMCAT, one snow particle equals one aerosol). The result is that deposition rates for large particles in p-TOMCAT are proportionally greater, while the burden and surface concentration are quite similar between the two models. However, for the smaller particles, the surface concentration and burden of sea salt are significantly lower in p-TOMCAT, leading to an Arctic lifetime of 1.7 days versus 6.6 days in GEOS-Chem.

Lack of observations of snow on sea ice in the Arctic, and of sea salt aerosol produced during blowing events, makes it difficult to constrain many of the key parameters related to the blowing snow SISS emission process. Although we use a snow salinity distribution double that of Antarctic observations, a snow age of $24 \mathrm{~h}$, and a $50 \%$ reduction in SISS emissions from multi-year sea ice relative to first-year sea ice in our base simulation, we understand that a different combination of these parameters could effectively produce the same results.

\subsection{Importance of sea-ice-sourced sea salt aerosol}

Despite the somewhat ambiguous choices of parameters that we have to make, it is important to note that in all the indi- vidual sensitivity tests conducted for 1997, SISS contributes to offset the winter OOSS Na deficit at all five Arctic aerosol sites (Fig. S5). For the full base simulation, the addition of SISS produces seasonal cycles that match well with overlapping Arctic aerosol observations. NRMSDs of between $34 \%$ for Villum and $89 \%$ for Alert (Fig. 3) are achieved. At Zeppelin on Svalbard, the modelled OOSS contribution is too high throughout the year. However, the seasonal profile of SISS looks promising - its amplitude is similar to the seasonal cycle of the observations. Villum, N. Greenland, shows the best model-observations agreement, with SISS contributing $80 \%$ of the total $\mathrm{Na}$ in the winter months on average. Results for Barrow, Alaska, are equally encouraging for January to June, but p-TOMCAT appears to underestimate SISS in the latter half of the year, hinting that SISS emission rates may vary with the cycle of sea ice decay and regrowth.

Only Alert, Canada, shows a significant offset between the aerosol observations and the modelled Na concentration (Fig. 3). The summer concentrations, dominated by OOSS match well, but in other months p-TOMCAT underestimates [Na]. Huang and Jaeglé (2017) had a similar problem estimating aerosol [Na] at Alert and suggested that it results from Alert being situated in a region of relatively calm and stable meteorological conditions where the threshold wind speed $\left(\sim 7 \mathrm{~m} \mathrm{~s}^{-1}\right)$ for SISS emissions is not reached as often. Huang and Jaeglé (2017) found that the inclusion of an explicitly parameterized frost flower source (Xu et al., 2013) helped to match the observed sea salt aerosol budget at Alert. Further field measurements are required to assess to what extent frost flowers do actually contribute aerosol to the atmospheric sea salt budget at low wind speeds, given evidence to the contrary (Obbard et al., 2009; Roscoe et al., 2011; Yang et al., 2017).

The simulated seasonal $\mathrm{Na}$ aerosol cycle for Summit, Greenland, matches the aerosol observations well (Fig. 3). Our results suggest that OOSS is the dominant source of $\mathrm{Na}$ to the high-altitude central interior of the Greenland ice sheet with significant SISS Na only present from November to March, contributing a maximum of $44 \%$ of the monthly Na budget.

\section{Comparison of p-TOMCAT simulations to ice core Na records}

We now examine our p-TOMCAT base simulation (Table 1) of deposited sea salt for 1991-1999 to investigate the contribution of SISS to sea salt concentrations of Greenland ice core records. All the ice cores we consider are located at $>2000 \mathrm{~m}$ elevation and $>100 \mathrm{~km}$ inland (Table 2) so maximum $\mathrm{Na}$ concentrations are $<100 \mathrm{ppb}$. Seasonal variability in $[\mathrm{Na}]$ is consistently characterized by winter maxima and summer minima (Fig. 5); the amplitude of the mean seasonal cycle in the different ice cores varies between 6 and $55 \mathrm{ppb}$. 
Table 3. Comparison between Arctic $\left(>60^{\circ} \mathrm{N}\right)$ sea salt aerosol budgets simulated by this study and by Huang and Jaeglé (2017) (in italics) for 2005. All values refer to mass of total sea salt aerosol, defined as Na mass multiplied by 0.326, following Huang and Jaeglé (2017). Please see footnotes for definitions of each term.

\begin{tabular}{|c|c|c|c|c|c|c|}
\hline & & OOSS & & & SISS & \\
\hline $\begin{array}{l}\text { This study } \\
\text { Huang and Jaeglé (2017) }\end{array}$ & $\begin{array}{r}0.01<r_{\text {dry }} \leq 0.57 \mu \mathrm{m} \\
0.01-0.5 \mu \mathrm{m}\end{array}$ & $\begin{array}{r}0.57<r_{\text {dry }} \leq 4.5 \mu \mathrm{m} \\
0.5-4 \mu \mathrm{m}\end{array}$ & $\begin{array}{l}\text { Total } \\
\text { Total }\end{array}$ & $\begin{array}{r}0.01<r_{\text {dry }} \leq 0.57 \mu \mathrm{m} \\
0.01-0.5 \mu \mathrm{m}\end{array}$ & $\begin{array}{r}0.57<r_{\mathrm{dry}} \leq 4.5 \mu \mathrm{m} \\
0.5-4 \mu \mathrm{m}\end{array}$ & $\begin{array}{l}\text { Total } \\
\text { Total }\end{array}$ \\
\hline Emission rate $\left(\mathrm{Tg} \mathrm{yr}^{-1}\right)$ & $\begin{array}{l}0.69 \\
0.78\end{array}$ & $\begin{array}{l}24 \\
29\end{array}$ & $\begin{array}{l}25 \\
30\end{array}$ & $\begin{array}{r}0.41 \\
1.0\end{array}$ & $\begin{array}{l}8.4 \\
1.6\end{array}$ & $\begin{array}{l}8.8 \\
2.6\end{array}$ \\
\hline Burden $(\mathrm{Gg})$ & $\begin{array}{r}3.0 \\
12\end{array}$ & $\begin{array}{l}24 \\
32\end{array}$ & $\begin{array}{l}27 \\
45\end{array}$ & $\begin{array}{r}1.6 \\
14\end{array}$ & $\begin{array}{l}1.9 \\
3.3\end{array}$ & $\begin{array}{r}3.5 \\
17\end{array}$ \\
\hline Surface concentration $\left(\mu \mathrm{g} \mathrm{m}^{-3}\right)$ & $\begin{array}{l}0.07 \\
0.19\end{array}$ & $\begin{array}{r}0.50 \\
1.0\end{array}$ & $\begin{array}{r}0.57 \\
1.2\end{array}$ & $\begin{array}{r}0.11 \\
0.4\end{array}$ & $\begin{array}{l}0.13 \\
0.17\end{array}$ & $\begin{array}{l}0.24 \\
0.57\end{array}$ \\
\hline Deposition rate $\left(\operatorname{Tg~yr}^{-1}\right)$ & $\begin{array}{r}0.85 \\
1.3\end{array}$ & $\begin{array}{l}25 \\
33\end{array}$ & $\begin{array}{l}26 \\
34\end{array}$ & $\begin{array}{l}0.34 \\
0.78\end{array}$ & $\begin{array}{l}8.3 \\
1.7\end{array}$ & $\begin{array}{l}8.6 \\
2.4\end{array}$ \\
\hline Lifetime in Arctic region (days) & $\begin{array}{l}1.3 \\
3.3\end{array}$ & $\begin{array}{l}0.35 \\
0.35\end{array}$ & $\begin{array}{l}0.38 \\
0.48\end{array}$ & $\begin{array}{l}1.7 \\
6.6\end{array}$ & $\begin{array}{l}0.08 \\
0.73\end{array}$ & $\begin{array}{r}0.15 \\
2.6\end{array}$ \\
\hline
\end{tabular}

Emission rate: mean rate of sea salt aerosol emission across the Arctic for 2005; Burden: annual mean total mass of sea salt aerosol present in the Arctic atmosphere (entire column) in 2005. Surface concentration: mean concentration of sea salt aerosol across the Arctic region in the surface layer of the atmosphere (as defined by model, in p-TOMCAT $\approx 46-72 \mathrm{~m} \mathrm{height)} \mathrm{in} 2005$; Deposition rate: mean rate of sea salt aerosol deposition (wet and dry removal) across the Arctic for 2005; Lifetime: lifetime of sea salt aerosol in the Arctic region calculated as burden

$(\mathrm{Tg}) /$ deposition rate $\left(\mathrm{Tg} \mathrm{yr}^{-1}\right)$. This value will be influenced by import or export of sea salt aerosol to/from the Arctic region (which must be occurring when emission rate $\neq$ deposition rate).

\subsection{Influence of snow accumulation rate}

Given that simulation of ice core Na concentrations using p-TOMCAT requires both the mass of Na deposited and the amount of precipitation at the ice core site (Eq. 6), it is important that p-TOMCAT simulates precipitation accurately. On the annual scale, the p-TOMCAT precipitation rates (forced towards GPCP observations, Sect. 2.3.1) agree well with ice core snow accumulation rates (Fig. 6a). Northern sites like NEEM and Tunu show model-ice core agreement to within $30 \%$. Summit annual mean snow accumulation rate is estimated to within $2 \%$. Further south, the model-ice core agreement reduces as p-TOMCAT has trouble capturing the steep gradient in snow accumulation rate between the coast and the interior of the ice sheet over southern Greenland. At ACT11d, for example, the simulated precipitation rate is $250 \%$ higher than that suggested by the ice core.

The simulated precipitation rate at a single Greenland ice core site can vary by a factor of 4 across a year (Fig. 6b-d). At NEEM in northwest Greenland, the simulated precipitation rate is consistently higher in summer relative to winter (Fig. 6b), whereas at Summit in central Greenland the simulated precipitation rate is greater in winter relative to summer (Fig. 6c). Ice core sites further south do not show a clear seasonal signal in model-calculated precipitation rate (Fig. 6d). We have a small amount of information about how snow accumulation rates over Greenland vary seasonally. Recent field measurements at Summit (2003-2014) agree with satellite-based laser altimetry measurements, indicating that the monthly accumulation rates are highly variable with a tendency towards relatively low snow accumulation in spring and relatively high snow accumulation in autumn (Fig. 6c).
Other work, focused on the Summit, NGRIP, and NEEM sites, found evidence for a summer-weighted bias in snow accumulation (Shuman et al., 1995, 2001; Steen-Larsen et al., 2011), suggesting p-TOMCAT may in fact be doing a good job of representing seasonal accumulation variability in northern Greenland (Fig. 6b).

We test the effect of substituting the constant monthly ice core snow accumulation rate for $A$ in Eq. (6) when calculating the $\mathrm{Na}$ concentration of snow falling at the ice core sites because a constant rate of snow accumulation per year was assumed when dating the ice core records. This does not remove all possible bias due to the modelled precipitation seasonality because the modelled precipitation is still in wet deposition calculations (Eq. 1). Simulated ice core [Na] calculated by this method are displayed in Fig. 5b, and simulated ice core $[\mathrm{Na}]$ calculated using the model-calculated snow accumulation rate in Eq. (6) are displayed in Fig. 5a.

At ice core sites where accumulation rates are overestimated by p-TOMCAT - i.e. D4, D5, Das2, and S. Greenland (ACT10C, ACT3, and Das1) - Na concentrations broadly increase when the (lower) ice core accumulation rate is used (Fig. 5b compared to Fig. 5a). Modelled precipitation for Summit (Fig. 6c), D4, D5, and Das2 is lower in April to June relative to other months causing a prominent springearly summer maximum in simulated $\mathrm{Na}$, specifically OOSS (Fig. 5a). Using the constant ice core accumulation rate this feature disappears and the [Na] maximum occurs in the winter months, in agreement with the ice core data seasonality (Fig. 5b). It is possible that the assumption of winter timing of $[\mathrm{Na}]$ peaks made in ice core dating is incorrect and that [Na] seasonality in Greenland ice cores is actually like the simulated profiles in Fig. 5a. However, this seems unlikely 


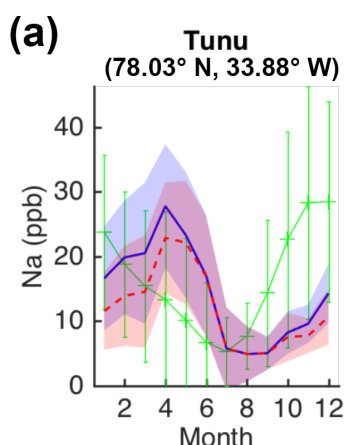

D4
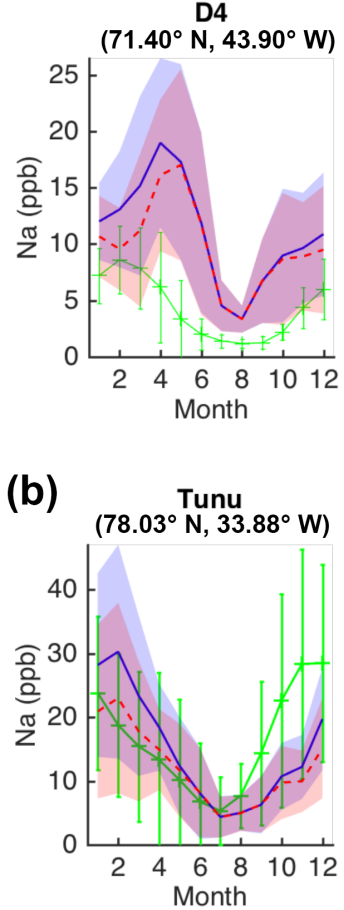

D4

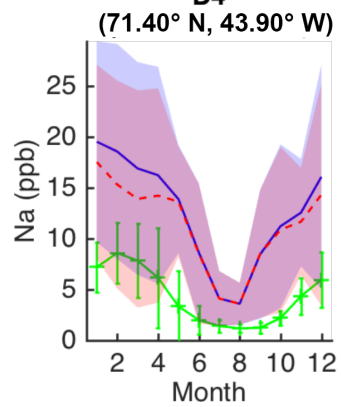

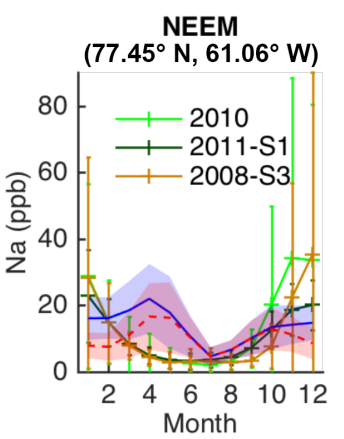

Das2

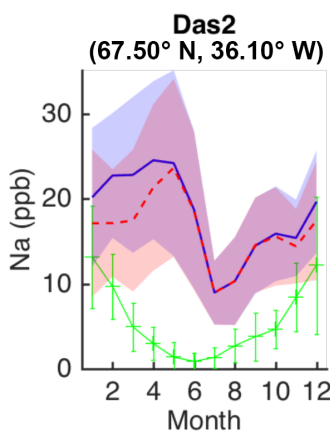

NEEM

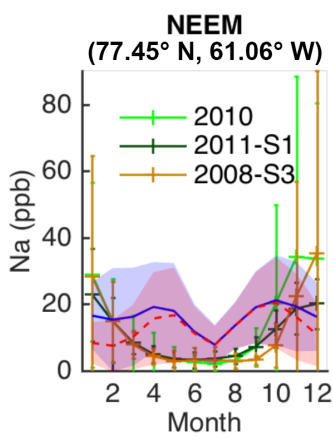

Das2

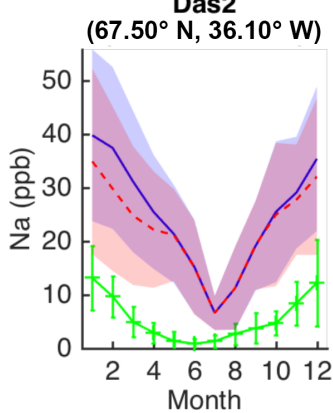

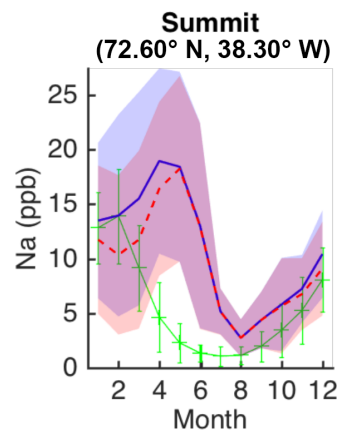
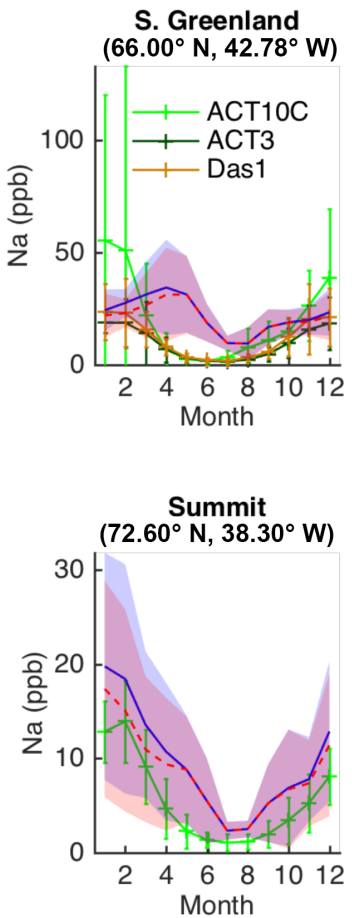

S. Greenland

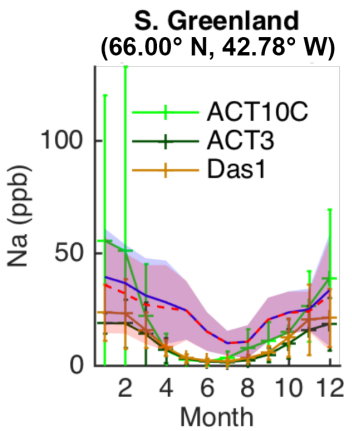

Figure 5. Mean monthly mean sea salt Na concentrations of Greenland ice cores simulated by p-TOMCAT for 1991-1999 compared to data. OOSS simulations (red dashed line) and combined OOSS and SISS simulations (blue line) are shown with uncertainty envelopes (red and blue shading respectively), representing $\pm 1 \sigma$ of the simulated inter-annual variability. Mean monthly ice core Na concentrations (green) are shown with uncertainty bars denoting $\pm 1 \sigma$ of the inter-annual variability. Two sub-plots feature three different ice core records located within the same p-TOMCAT grid box, as indicated by the legend. Two different options for simulated sea salt concentrations are displayed: (a) $[\mathrm{Na}]$ calculated using p-TOMCAT precipitation output in Eq. (5) and (b) [Na] calculated using the constant annual accumulation rate indicated by the ice core records (Table 2) in Eq. (5). In both cases, the p-TOMCAT monthly mean time series has been smoothed using a Savitzky-Golay filter (span $4 \%$, order 2) prior to stacking of the monthly mean values for 1991-1999 (Sect. 4.2). 


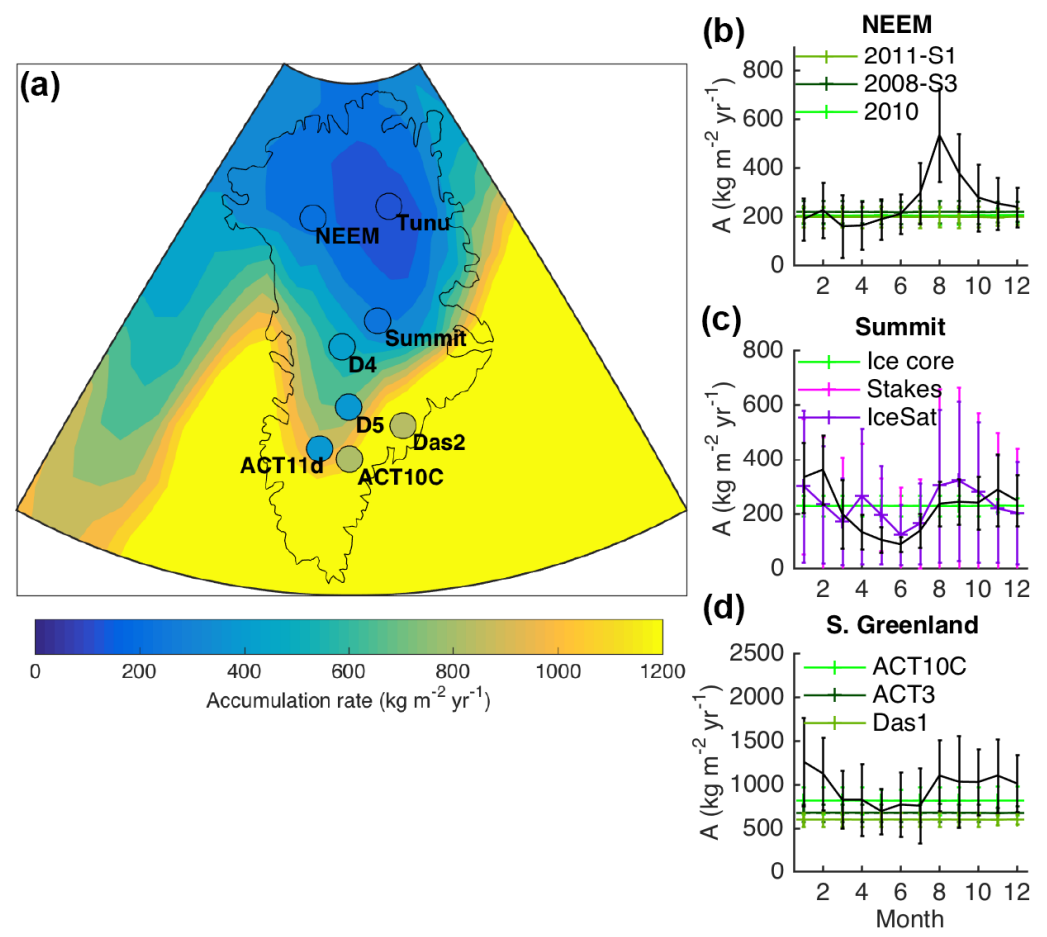

Figure 6. Comparison between Greenland ice core snow accumulation rates and simulated precipitation rates for 1991-1999. (a) Map of Greenland showing contoured simulated annual accumulation rate. Actual ice core accumulation rates for the 1990s are shown as infilled circles. (b-d) Seasonal variability of accumulation rate simulated by p-TOMCAT (black) and the constant annual accumulation rate estimated by ice core dating (green shades). Also displayed on (c) are snow accumulation rates measured at Summit 2003-2014 (purple shades): "Stakes", field measurements of snow accumulation at bamboo stakes; "IceSat", laser altimetry measurements from ICESat (Zwally et al., 2002). These snow accumulation records have been converted to water-equivalent accumulation rate assuming a snow density of $0.34 \mathrm{~g} \mathrm{~cm}{ }^{-3}$. All records are shown with uncertainty bars representing $\pm 1 \sigma$ of inter-annual variability.

because [Na] values of Greenland aerosol (Fig. 3) and fresh surface snow at Summit (Fig. S6) peak in the winter months.

\subsection{Smoothing of the snowpack Na signal}

Comparison between p-TOMCAT [Na] simulations and Greenland ice core records reveal significant month-tomonth variability in the simulated time series that is not present in the ice core records, which are all characterized by smoothly oscillating [Na] with a clear seasonality (Fig. 7). We hypothesize that the deposited $\mathrm{Na}$ signal is smoothed by surface snow redistribution by winds and compaction of the snow pack during densification (Dibb and Jaffrezo, 1997). Evidence for this smoothing process comes from comparison of Na concentrations of weekly surface snow samples at Summit and ice core [Na] measurements dating from the same time interval (Fig. S6). The surface snow Na concentrations are much more variable with rapid, large $(\sim 20 \mathrm{ppb})$ oscillations. However, the timing and magnitude of the underlying seasonal cycle corresponds well with the ice core record. The ice core [Na] signal may also be damped by dispersive mixing within the continuous analysis system (Breton et al., 2012), specifically for lower snow accumulation sites such as Tunu. We crudely represent the cumulative ef- fect of these smoothing processes by applying a SavitzkyGolay filter $(\operatorname{span}=4 \%$, order $=2)$ to the simulated $[\mathrm{Na}]$ time series (Fig. 7). The stacked simulated [Na] seasonal cycles for 1991-1999 are displayed in Fig. 5. Unfiltered Na seasonal cycle stacks are displayed in Fig. S6.

\subsection{How well are Greenland ice core records represented by p-TOMCAT?}

\subsubsection{Annual mean}

The majority of Greenland ice core annual mean [Na] values (1991-1999) are simulated to within a factor of 2 by pTOMCAT (Fig. 8a, Table 4). Tunu, NEEM, and ACT10C annual means are simulated most accurately, regardless of the accumulation rate used to calculate the simulated $[\mathrm{Na}$ ] (Tables 4 and S1 in the Supplement). Das2 in southeast Greenland and ACT11d and ACT2 is southwest Greenland are the most poorly simulated with p-TOMCAT overestimating the extremely low ice core annual mean [Na] values of 5-8 ppb by $>350 \%$ (Fig. 8a, Table 4). p-TOMCAT severely overestimates the accumulation rate for these sites (Fig. 6a), suggesting that too much sea salt is deposited by wet deposition. 

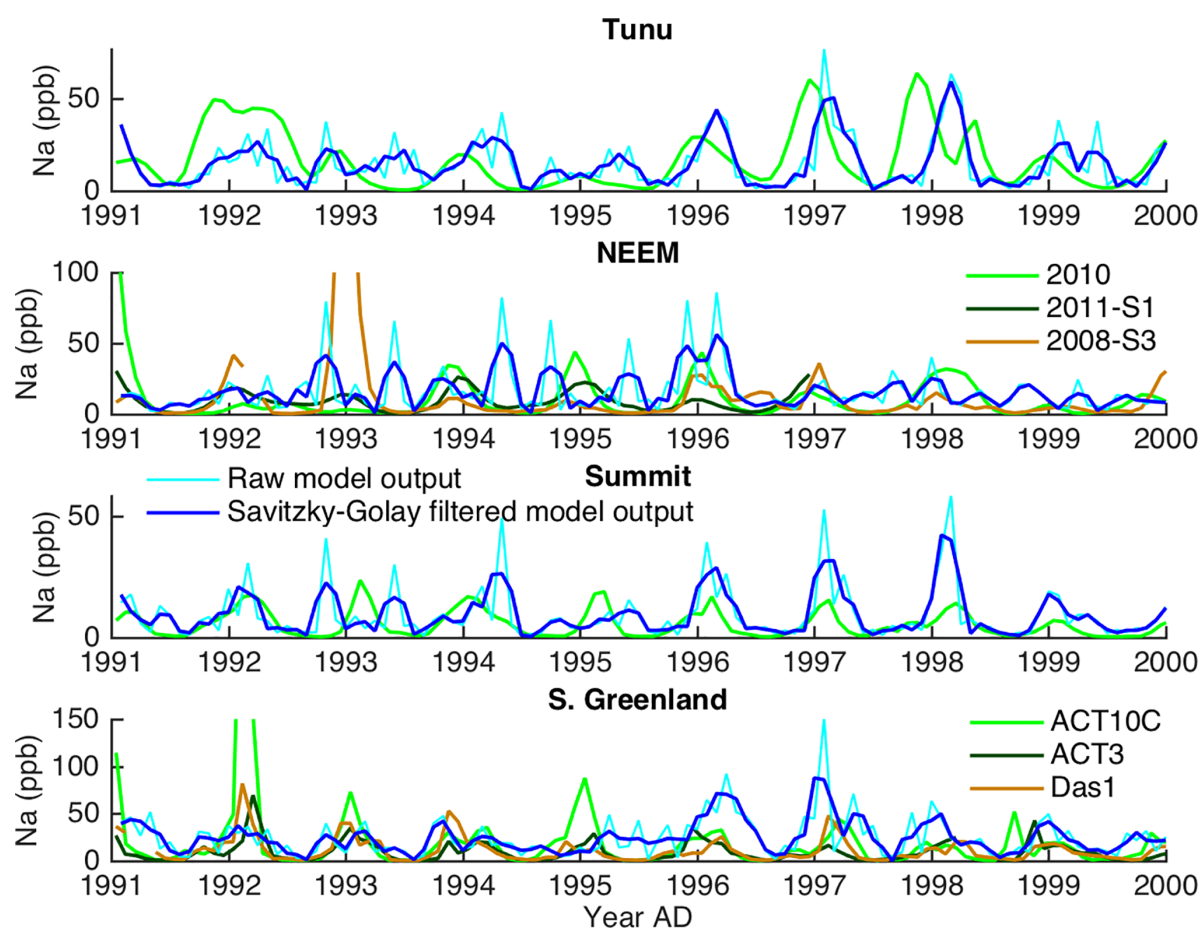

Figure 7. Time series of Greenland ice core [Na] (bright green, dark green, and dark orange) and p-TOMCAT simulated [Na] in Greenland snow 1991-1999 (raw, cyan; smoothed, blue). Data from three different ice cores are displayed on the NEEM and S. Greenland panels because they are located in the same grid square in p-TOMCAT (Table 2). Simulated [Na] is calculated using the constant annual snow accumulation rate indicated by the ice core records in Eq. (5). Simulated [Na] calculated using p-TOMCAT accumulation rates is out of phase with ice core data at some sites (see Fig. 5a).

\subsubsection{Seasonal cycle}

p-TOMCAT is also successful in simulating the amplitude of the seasonal cycle of [Na] in the majority of Greenland ice cores to within a factor of 2 (Fig. 8 b, Table 4), giving us confidence that p-TOMCAT is simulating meaningful seasonal variability. Again, the northerly sites are simulated most accurately: Tunu to within $1 \mathrm{ppb}$ and Summit to within $4 \mathrm{ppb}$ (Table 4). The seasonal cycles in the southern cores of ACT2 and ACT11d (Table 4) are overestimated, which can be linked to the high simulated snow accumulation rates.

At central and southern sites simulated summer (JJA) [Na] values are higher than the ice core data (Table 4), often by a factor of 5 or more, but we note that summer ice core [Na] values can be as low as $1 \mathrm{ppb}$. It is interesting that the summer OOSS contribution to the ice core budget is overestimated by p-TOMCAT because simulated aerosol OOSS concentrations in the surface layer of the atmosphere at Villum, Barrow, and Alert appear to match summer observations well (Fig. 3). At Summit, correspondence with summer observations is greatly improved if the full 1991-2006 simulation mean is considered (not shown). We suspect this difference between aerosol and ice core simulations results from the simplistic deposition scheme of p-TOMCAT, which allows super-micron-sized OOSS particles to be transported to the ice sheet and wet-deposited from high levels in the atmosphere (Fig. S3). The deposition scheme does not differentiate between in-cloud and below-cloud scavenging rates (Zhang et al., 2013) and wet deposition rates are the same when precipitation is snow or rain (Wang et al., 2014). There is also no explicit consideration of fog deposition, which is common on the Greenland ice sheet (Bergin et al., 1995).

\subsubsection{Inter-annual variability}

To test whether or not p-TOMCAT shows any skill at reproducing the inter-annual variability in ice core $[\mathrm{Na}]$ we regress the annual mean $[\mathrm{Na}]$, annual maximum $[\mathrm{Na}]$ and the interannual $[\mathrm{Na}]$ difference of the ice cores against the equivalent values simulated by p-TOMCAT, calculated using both options for accumulation rate (Table S2). In many cases, the sign of regression is negative, or close to zero, indicating that p-TOMCAT has no skill at all. However, in four cases we obtain significant $(p \leq 0.05)$ positive correlations between ice core data and model simulation. These results indicate that p-TOMCAT captures 54 and $43 \%$ of the inter-annual variability in the annual mean [Na] and annual maximum [Na] respectively at Summit, and $62 \%$ of the year-to-year change in annual mean [Na]. $58 \%$ of the inter-annual variability in annual maximum [Na] at NEEM-2008-S3 is also captured by p-TOMCAT. 
Table 4. Mean sea salt Na concentrations for 1991-1999 recorded in ice cores (bold) and simulated by p-TOMCAT calculated using modelled precipitation rates in Eq. (5). See Table S1 for equivalent values calculated using ice core snow accumulation rates.

\begin{tabular}{|c|c|c|c|c|c|}
\hline Ice core & $\begin{array}{r}\text { Annual } \\
{[\mathrm{Na}]} \\
(\mathrm{ppb})\end{array}$ & $\begin{array}{r}\text { DJF } \\
{[\mathrm{Na}]} \\
(\mathrm{ppb})\end{array}$ & $\begin{array}{r}\text { JJA } \\
{[\mathrm{Na}]} \\
(\mathrm{ppb})\end{array}$ & $\begin{array}{r}\text { Seasonal } \\
{\text { cycle }[\mathrm{Na}]^{\mathrm{a}}}^{\mathrm{a}} \\
(\mathrm{ppb})\end{array}$ & $\begin{array}{r}\text { DJF } \\
\text { SISS : } \\
\text { OOSS }\end{array}$ \\
\hline \multirow[t]{2}{*}{ Tunu } & 16 & 24 & 7 & 22 & \\
\hline & 14 & 17 & 9 & 23 & 0.4 \\
\hline \multirow[t]{2}{*}{ NEEM-2008-S3 } & 11 & 25 & 3 & 31 & \\
\hline & 14 & 16 & 7 & 17 & 1.0 \\
\hline \multirow[t]{2}{*}{ Summit } & 6 & 12 & 1 & 13 & \\
\hline & 11 & 13 & 7 & 16 & 0.2 \\
\hline \multirow[t]{2}{*}{ D4 } & 4 & 8 & 1 & 8 & \\
\hline & 11 & 12 & 7 & 16 & 0.2 \\
\hline \multirow[t]{2}{*}{ D5 } & 8 & 13 & 4 & 10 & \\
\hline & 14 & 16 & 8 & 19 & 0.2 \\
\hline \multirow[t]{2}{*}{ Das2 } & 5 & 12 & 2 & 12 & \\
\hline & 18 & 21 & 13 & 16 & 0.2 \\
\hline \multirow[t]{2}{*}{$\operatorname{Das} 1^{b}$} & 11 & 23 & 2 & 23 & \\
\hline & 22 & 25 & 13 & 25 & 0.1 \\
\hline \multirow[t]{2}{*}{$\mathrm{ACT} 10 \mathrm{C}^{\mathrm{b}}$} & 21 & 49 & 4 & 55 & \\
\hline & 22 & 25 & 13 & 25 & 0.1 \\
\hline \multirow[t]{2}{*}{$\mathrm{ACT}^{\mathrm{b}}$} & 9 & 19 & 2 & 18 & \\
\hline & 22 & 25 & 13 & 25 & 0.1 \\
\hline \multirow[t]{2}{*}{$\mathrm{ACT} 2^{\mathrm{c}}$} & 8 & 13 & 3 & 10 & \\
\hline & 25 & 24 & 16 & 31 & 0.1 \\
\hline \multirow[t]{2}{*}{$\mathrm{ACT} 11 \mathrm{~d}^{\mathrm{c}}$} & 7 & 10 & 5 & 7 & \\
\hline & 25 & 24 & 16 & 31 & 0.1 \\
\hline
\end{tabular}

a Seasonal cycle is the maximum monthly mean $[\mathrm{Na}]$ minus the minimum monthly mean [Na]. ${ }^{\mathrm{b}}$ Same grid square in p-TOMCAT so simulated values are equal. ${ }^{\mathrm{c}}$ Same grid square in p-TOMCAT so simulated values are equal.

These results are promising, given that 1991 to 1999 is a relatively short time series for comparison. Additionally, it is unlikely that a chemical transport model could explain a greater proportion of inter-annual variability in ice core [Na] than achieved here. This is because ice core chemistry records are affected by several factors that impact the final record preserved, in addition to the meteorology and source conditions parameterized by p-TOMCAT. Factors such as snow redistribution and wind-generated features such as sastrugi can cause chemistry (Gfeller et al., 2014) and accumulation rate (Mosley-Thompson et al., 2001) records from proximal ice cores to differ; Dibb and Jaffrezo (1997) found annual mean $[\mathrm{Na}$ ] of the snowpack at Greenland varied by up $30 \%$ between sites $<1 \mathrm{~km}$ apart. We can see that this is the case by comparing the different NEEM ice core records or S. Greenland ice core records in Fig. 5 or 7 that show significant differences in $[\mathrm{Na}]$ despite being located in the same p-TOMCAT grid box.
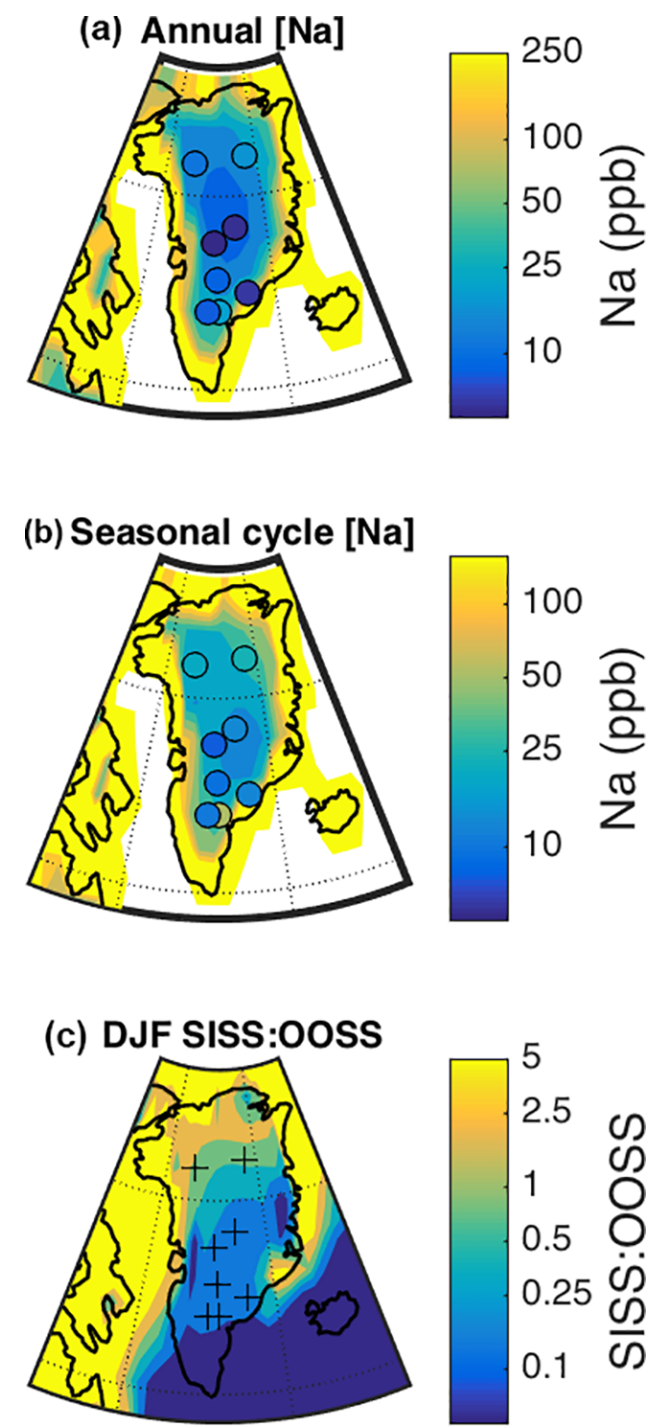

Figure 8. Greenland ice core [Na] simulated by p-TOMCAT (19911999) compared to Greenland ice core data (circles). (a) Annual mean $[\mathrm{Na}]$, (b) seasonal cycle in $[\mathrm{Na}]$ (maximum monthly [Na] minus minimum monthly [Na], and (c) winter (DJF) SISS : OOSS ratio (simulated) with black crosses marking ice core locations. Simulated $[\mathrm{Na}]$ values calculated using the modelled accumulation rate (see Table S1 for alternative values at each ice core site if ice core accumulation rate is used). Note the log scales to all colour bars.

\section{Importance of sea-ice-sourced sea salt for Greenland ice core records}

Results from our base simulation for 1991-1999 suggest that SISS makes an important contribution to the sea salt budget of some Greenland ice cores during winter and the shoulder seasons. In our simulations, SISS accounts for between 10 and $50 \%$ of the winter sea salt budget of Greenland ice cores (Fig. 8c, Table 4). The SISS : OOSS ratio is marked by a north-south gradient across Greenland as more northerly sites, closer to sea ice, show elevated SISS relative to OOSS 
(Fig. 8c). SISS : OOSS also increases to the west of Greenland where the prevailing wind comes across the sea ice of Hudson Bay. Our examination of simulated summer (JJA) $[\mathrm{Na}]$ values suggests that OOSS reaching inland Greenland locations may be overestimated. A reduced contribution from OOSS would allow for a greater contribution from SISS in order to match ice core measurements, particularly the seasonal cycle amplitude.

It is likely that the SISS : OOSS ratio was greater in the past when temperatures were cooler and Arctic sea ice was expanded, for example during the Last Glacial Period. Running p-TOMCAT with prescribed sea ice and meteorology for palaeo-conditions will allow us to test this.

All the ice cores, apart from NEEM, show a seasonality in OOSS (minimum concentration in summer and maximum in winter-spring) (Fig. 5). We speculate that this results from the seasonal bias toward relatively low summer precipitation and relatively high winter-spring precipitation in the p-TOMCAT model (Fig. 6c-d) because the amount and frequency of precipitation dictate the rate of wet deposition at the ice core sites (Eq. 1). This OOSS seasonality in Greenland ice cores appears to contrast with the relatively constant monthly OOSS aerosol simulated by p-TOMCAT at most Arctic aerosol sites (Fig. 3). However, the OOSS aerosol simulations for Summit do show similar seasonality to the ice cores; this is more apparent when results from the entire 1991-2006 simulation are considered rather than those from the 2003-2006 window displayed in Fig. 3.

Summer ice core Na concentrations apparently reflect only OOSS Na levels (Fig. 5). This agrees with Arctic aerosol observations and simulations (Fig. 3). For Summit, Greenland, we can model the Na loading of the surface atmosphere and the Na concentration of the deposited snow. Both agree that summer minima reflect OOSS and that winter maxima are supplemented by SISS.

\section{Summary}

This study supports Levine et al. (2014), Legrand et al. (2016), and Huang and Jaeglé (2017), who all argue for the importance of a winter source of sea salt aerosol from the sea ice surface to the aerosol budget of the polar regions. We demonstrate that winter SISS is required, in addition to OOSS, in order to reproduce the magnitude and seasonality of aerosol observations of sea salt at five Arctic locations across Alaska, Canada, Greenland, and Svalbard.

For the first time, we use a chemical transport model to explicitly simulate the Na concentration of snow deposited on the Greenland ice sheet to within a factor of 2. Our simulations for 1991-1999 suggest that SISS contributes to the winter maxima observed in all the ice cores, but that in most cases, OOSS alone can produce winter maxima and summer minima in sea salt in ice cores. A north-south gradient in the contribution of SISS to the total winter ice core sea salt bud- get is simulated across Greenland, with $50 \%$ of sea salt being SISS at NEEM and only $10 \%$ at southern Greenland sites, such as ACT10C. This spatial pattern hints that comparison between cores from northern and southern Greenland could help to isolate any independent change in SISS relative to OOSS.

p-TOMCAT shows some skill in simulating the interannual variability of [Na] in the ice core records from NEEM and particularly Summit, where $62 \%$ of the inter-variability in annual mean $[\mathrm{Na}]$ is captured by the model (Table S2). Future work will use the model simulations to assess what factor(s) is driving the inter-annual variability.

Our chemical transport model simulations suggest that [Na] records from Greenland ice cores can only inform us about winter, or maximum seasonal sea ice extent, under present-day conditions. In the summer months, SISS contributions to the sea salt budget are virtually zero so any change in summer sea ice extent over time is unlikely to be recorded, unless the ratio of SISS to OOSS is changed substantially. Other ice core proxies, such as methanesulfonate, which is linked to primary productivity in the surface ocean, should be considered for reconstructing Arctic summer sea ice conditions (Maselli et al., 2017).

More Arctic observations of blowing snow events (particle size and chemical composition) and snow on the sea ice surface (salinity and its seasonally resolved evolution with time) are required before process-based modelling of blowing snow SISS emissions can be improved.

Data availability. All ice core model simulations produced in this study are available in the Supplement. Sea salt concentration fields for the atmosphere and snowfall are available as NetCDF files on request from R. H. Rhodes (rhr34@cam.ac.uk). Greenland ice core data are available at https://arcticdata.io/ or in the Supplement. Arctic aerosol data used in this study from Alert (Canada), Zeppelin Station (Svalbard), and Villum Station in N. Greenland are available at http://ebas.nilu.no/ (EBAS database, Norwegian Institute for Air Research (NILU)). Summit (central Greenland) aerosol and surface snow $\mathrm{Na}$ data are available at https://arcticdata.io/catalog/\#view/ urn:uuid:e9136a64-661f-470d-9b3a-72f31d54d066 (Bales, 2009). Aerosol chemistry data from the AEROCE-SEAREX networks are available at http://aerocom.met.no/download/AEROCE-SEAREX/. Salinity profiles of snow on sea ice in the Weddell Sea (Antarctica) collected for the BLOWSEA project during austral winter 2013 are located at (https://doi.org/10.5285/c0261633-fd14-4d45-a58d72998816c4cd; Frey, 2017).

\section{Information about the Supplement}

Figures S1-S7, Tables S1-S2, Greenland ice core Na data, and simulations are located in the Supplement.

The Supplement related to this article is available online at https://doi.org/10.5194/acp-17-9417-2017-supplement. 
Competing interests. The authors declare that they have no conflict of interest.

Acknowledgements. This work was supported by a European Commission Horizon 2020 Marie Sklodowska-Curie Individual Fellowship (no. 658120, SEADOG) to Rachael H. Rhodes. Eric W. Wolff is supported by a Royal Society Professorship. Xin Yang and Markus Frey gratefully acknowledge financial support from Natural Environment Research Council (UK) through the BLOWSEA project (NE/J023051/1). We thank Wuhu Feng and Martin Chipperfield at University of Leeds for support in using ERA-Interim data and the ICT Unix team at the British Antarctic Survey for their help running p-TOMCAT. The Greenland ice cores were collected and analysed under numerous NSF Office of Polar Programs grants, including 021515, 0856845, 0909499, 0909499, and 1204176, as well as NASA grants NAG512752 and NAG04GI66G. This international collaboration was supported partially by NSF grant 0968391 . We are grateful to the students, staff, and numerous collaborators of the Desert Research Institute ultra-trace ice core chemistry laboratory for help in collecting and analysing the ice cores.

Edited by: Jianzhong Ma

Reviewed by: two anonymous referees

\section{References}

Abram, N. J., Wolff, E. W., and Curran, M. A.: A review of sea ice proxy information from polar ice cores, Quaternary Sci. Rev., 79, 168-183, 2013

Adler, R. F., Huffman, G. J., Chang, A., Ferraro, R., Xie, P.-P., Janowiak, J., Rudolf, B., Schneider, U., Curtis, S., Bolvin, D., Gruber, A., Susskind, J., Arkin, P., and Nelkin, E.: The Version-2 Global Precipitation Climatology Project (GPCP) Monthly Precipitation Analysis (1979-Present), J. Hydrometeorol., 4, 1147-1167, https://doi.org/10.1175/15257541(2003)004<1147:TVGPCP>2.0.CO;2, 2003.

Bales, R.: Core Atmospheric Measurements at Summit, Greenland Environmental Observatory, Arctic Data Center, urn:uuid:e9136a64-661f-470d-9b3a72f31d54d066, https://arcticdata.io/catalog/\#view/urn:uuid: e9136a64-661f-470d-9b3a-72f31d54d066, 2009.

Banta, J. R., McConnell, J. R., Edwards, R., and Engelbrecht, J. P.: Delineation of carbonate dust, aluminous dust, and sea salt deposition in a Greenland glaciochemical array using positive matrix factorization, Geochem. Geophy. Geosy., 9, Q07013, https://doi.org/10.1029/2007GC001908, 2008.

Barrie, L. A.: Arctic Aerosols: Composition, Sources and Transport, in: Ice Core Studies of Global Biogeochemical Cycles, edited by: Delmas, R. J., NATO ASI Series, Springer Berlin Heidelberg, 122, https://doi.org/10.1007/978-3-642-51172-1_1, 1995.

Bergin, M. H., Jaffrezo, J.-L., Davidson, C. I., Dibb, J. E., Pandis, S. N., Hillamo, R., Maenhaut, W., Kuhns, H. D., and Makela, T.: The contributions of snow, fog, and dry deposition to the summer flux of anions and cations at Summit, Greenland, J. Geophys. Res.-Atmos., 100, 16275-16288, https://doi.org/10.1029/95JD01267, 1995.
Box, J. E., Bromwich, D. H., and Bai, L.-S.: Greenland ice sheet surface mass balance 1991-2000: Application of Polar MM5 mesoscale model and in situ data, J. Geophys. Res.-Atmos., 109, D16105, https://doi.org/10.1029/2003JD004451, 2004.

Breton, D. J., Koffman, B. G., Kurbatov, A. V., Kreutz, K. J., and Hamilton, G. S.: Quantifying signal dispersion in a hybrid ice core melting system, Environ. Sci. Technol., 46, 11922-11928, https://doi.org/10.1021/es302041k, 2012.

Butler, B. M. and Kennedy, H.: An investigation of mineral dynamics in frozen seawater brines by direct measurement with synchrotron X-ray powder diffraction, J. Geophys. Res.-Oceans, 120, 5686-5697, https://doi.org/10.1002/2015JC011032, 2015.

Cox, G. F. N. and Weeks, W. F.: Salinity Variations in Sea Ice, J. Glaciol., 13, 109-120, https://doi.org/10.1017/S0022143000023418, 1974.

Dee, D. P., Uppala, S. M., Simmons, A. J., Berrisford, P., Poli, P., Kobayashi, S., Andrae, U., Balmaseda, M. A., Balsamo, G., Bauer, P., Bechtold, P., Beljaars, A. C. M., van de Berg, L., Bidlot, J., Bormann, N., Delsol, C., Dragani, R., Fuentes, M., Geer, A. J., Haimberger, L., Healy, S. B., Hersbach, H., Hólm, E. V., Isaksen, L., Kållberg, P., Köhler, M., Matricardi, M., McNally, A. P., Monge-Sanz, B. M., Morcrette, J.-J., Park, B.-K., Peubey, C., de Rosnay, P., Tavolato, C., Thépaut, J.-N., and Vitart, F.: The ERA-Interim reanalysis: configuration and performance of the data assimilation system, Q. J. Roy. Meteor. Soc., 137, 553-597, https://doi.org/10.1002/qj.828, 2011.

DeMott, P. J., Hill, T. C. J., McCluskey, C. S., Prather, K. A., Collins, D. B., Sullivan, R. C., Ruppel, M. J., Mason, R. H., Irish, V. E., Lee, T., Hwang, C.Y., Rhee, T. S., Snider, J. R., McMeeking, G. R., Dhaniyala, S., Lewis, E. R., Wentzell, J. J. B., Abbatt, J., Lee, C., Sultana, C. M., Ault, A. P., Axson, J. L., Martinez, M. D., Venero, I., Santos-Figueroa, G., Stokes, M. D., Deane, G. B., Mayol-Bracero, O. L., Grassian, V. H., Bertram, T. H., Bertram, A. K., Moffett, B. F., and Franc, G. D.: Sea spray aerosol as a unique source of ice nucleating particles, P. Natl. Acad. Sci. USA, 113, 5797-5803. https://doi.org/10.1073/pnas.1514034112, 2016.

Déry, S. J. and Yau, M. K.: Simulation of blowing snow in the Canadian Arctic using a double-moment model, Bound.-Lay. Meteorol., 99, 297-316, 2001.

Dibb, J. E. and Jaffrezo, J.-L.: Air-snow exchange investigations at Summit, Greenland: An overview, J. Geophys. Res.-Oceans, 102, 26795-26807, https://doi.org/10.1029/96JC02303, 1997.

Domine, F., Sparapani, R., Ianniello, A., and Beine, H. J.: The origin of sea salt in snow on Arctic sea ice and in coastal regions, Atmos. Chem. Phys., 4, 2259-2271, https://doi.org/10.5194/acp4-2259-2004, 2004.

Frey, M. M.: Salinity profiles of snow on sea ice in the Weddell Sea (Antarctica) during austral winter 2013, NERC - Polar Data Centre, Cambridge, UK, https://doi.org/10.5285/c0261633-fd144d45-a58d-72998816c4cd, 2017.

Gfeller, G., Fischer, H., Bigler, M., Schüpbach, S., Leuenberger, D., and Mini, O.: Representativeness and seasonality of major ion records derived from NEEM firn cores, The Cryosphere, 8, 1855-1870, https://doi.org/10.5194/tc-8-1855-2014, 2014.

Giannakopoulos, C., Good, P., Law, K. S., Wang, K.-Y., Akylas, E., and Koussis, A.: Rainfall parameterization in an offline chemical transport model, Atmos. Sci. Lett., 5, 82-88, https://doi.org/10.1002/asl.68, 2004. 
Gong, S. L.: A parameterization of sea-salt aerosol source function for sub- and super-micron particles, Global Biogeochem. Cy., 17, 1097, https://doi.org/10.1029/2003GB002079, 2003.

Gong, S. L., Barrie, L. A., and Lazare, M.: Canadian Aerosol Module (CAM): A size-segregated simulation of atmospheric aerosol processes for climate and air quality models 2 . Global sea-salt aerosol and its budgets, J. Geophys. Res.-Atmos., 107, 4779, https://doi.org/10.1029/2001JD002004, 2002.

Huang, J. and Jaeglé, L.: Wintertime enhancements of sea salt aerosol in polar regions consistent with a sea ice source from blowing snow, Atmos. Chem. Phys., 17, 3699-3712, https://doi.org/10.5194/acp-17-3699-2017, 2017.

Jaeglé, L., Quinn, P. K., Bates, T. S., Alexander, B., and Lin, J.-T.: Global distribution of sea salt aerosols: new constraints from in situ and remote sensing observations, Atmos. Chem. Phys., 11, 3137-3157, https://doi.org/10.5194/acp-11-3137-2011, 2011.

Jones, A. E., Anderson, P. S., Begoin, M., Brough, N., Hutterli, M. A., Marshall, G. J., Richter, A., Roscoe, H. K., and Wolff, E. W.: BrO, blizzards, and drivers of polar tropospheric ozone depletion events, Atmos. Chem. Phys., 9, 4639-4652, https://doi.org/10.5194/acp-9-4639-2009, 2009.

Jourdain, B., Preunkert, S., Cerri, O., Castebrunet, H., Udisti, R., and Legrand, M.: Year-round record of size-segregated aerosol composition in central Antarctica (Concordia station): Implications for the degree of fractionation of sea-salt particles, J. Geophys. Res., 113, D14308, https://doi.org/10.1029/2007jd009584, 2008.

Kaleschke, L., Richter, A., Burrows, J., Afe, O., Heygster, G., Notholt, J., Rankin, A. M., Roscoe, H. K., Hollwedel, J., Wagner, T., and Jacobi, H.-W.: Frost flowers on sea ice as a source of sea salt and their influence on tropospheric halogen chemistry, Geophys. Res. Lett., 31, L16114, https://doi.org/10.1029/2004GL020655, 2004.

Keene, W. C., Pszenny, A. A. P., Jacob, D. J., Duce, R. A., Galloway, J. N., Schultz-Tokos, J. J., Sievering, H., and Boatman, J. F.: The geochemical cycling of reactive chlorine through the marine troposphere, Global Biogeochem. Cy., 4, 407-430, https://doi.org/10.1029/GB004i004p00407, 1990.

Knipping, E. M. and Dabdub, D.: Impact of chlorine emissions from sea-salt aerosol on coastal urban ozone, Environ. Sci. Technol., 37, 275-284, https://doi.org/10.1021/es025793z, 2003.

Krnavek, L., Simpson, W. R., Carlson, D., Domine, F., Douglas, T. A., and Sturm, M.: The chemical composition of surface snow in the Arctic: Examining marine, terrestrial, and atmospheric influences, Atmos. Environ., 50, 349-359, https://doi.org/10.1016/j.atmosenv.2011.11.033, 2012.

Legrand, M., Yang, X., Preunkert, S., and Theys, N.: Yearround records of sea salt, gaseous, and particulate inorganic bromine in the atmospheric boundary layer at coastal (Dumont d'Urville) and central (Concordia) East Antarctic sites: sea salt and bromine in Antarctica, J. Geophys. Res.-Atmos., 121, 9971023, https://doi.org/10.1002/2015JD024066, 2016.

Levine, J. G., Yang, X., Jones, A. E., and Wolff, E. W.: Sea salt as an ice core proxy for past sea ice extent: A process-based model study, J. Geophys. Res.-Atmos., 119, 2013JD020925, https://doi.org/10.1002/2013JD020925, 2014.

Mann, G. W., Anderson, P. S., and Mobbs, S. D.: Profile measurements of blowing snow at Halley, Antarc- tica, J. Geophys. Res.-Atmos., 105, 24491-24508, https://doi.org/10.1029/2000JD900247, 2000.

Maselli, O. J., Chellman, N. J., Grieman, M., Layman, L., McConnell, J. R., Pasteris, D., Rhodes, R. H., Saltzman, E., and Sigl, M.: Sea ice and pollution-modulated changes in Greenland ice core methanesulfonate and bromine, Clim. Past, 13, 39-59, https://doi.org/10.5194/cp-13-39-2017, 2017.

Massom, R. A., Eicken, H., Hass, C., Jeffries, M. O., Drinkwater, M. R., Sturm, M., Worby, A. P., Wu, X., Lytle, V. I., Ushio, S., Morris, K., Reid, P. A., Warren, S. G., and Allison, I.: Snow on Antarctic sea ice, Rev. Geophys., 39, 413-445, https://doi.org/10.1029/2000RG000085, 2001.

McConnell, J. R., Lamorey, G. W., Lambert, S. W., and Taylor, K. C.: Continuous ice-core chemical analyses using inductively coupled plasma mass spectrometry, Environ. Sci. Technol., 36, 7-11, https://doi.org/10.1021/es011088z, 2002.

Monahan, E. C., Spiel, D. E., and Davidson, K. L.: A model of marine aerosol generation via whitecaps and wave disruption, in: Oceanic Whitecaps: And Their Role in AirSea Exchange Processes, Springer Netherlands, 167-174, https://doi.org/10.1007/978-94-009-4668-2_16, 1986.

Mosley-Thompson, E., McConnell, J. R., Bales, R. C., Li, Z., Lin, P.-N., Steffen, K., Thompson, L. G., Edwards, R., and Bathke, D.: Local to regional-scale variability of annual net accumulation on the Greenland ice sheet from PARCA cores, J. Geophys. Res.-Atmos., 106, 33839-33851, https://doi.org/10.1029/2001JD900067, 2001.

Mundy, C. J., Barber, D. G., and Michel, C.: Variability of snow and ice thermal, physical and optical properties pertinent to sea ice algae biomass during spring, J. Mar. Syst., 58, 107-120, https://doi.org/10.1016/j.jmarsys.2005.07.003, 2005.

Murphy, D. M., Anderson, J. R., Quinn, P. K., McInnes, L. M., Brechtel, F. J., Kreidenweis, S. M., Middlebrook, A. M., Pósfai, M., Thomson, D. S., and Buseck, P. R.: Influence of sea-salt on aerosol radiative properties in the Southern Ocean marine boundary layer, Nature, 392, 62-65, https://doi.org/10.1038/32138, 1998.

Nishimura, K. and Nemoto, M.: Blowing snow at Mizuho station, Antarctica, Philos. T. R. Soc. A, 363, 1647-1662, https://doi.org/10.1098/rsta.2005.1599, 2005.

Obbard, R. W., Roscoe, H. K., Wolff, E. W., and Atkinson, H. M.: Frost flower surface area and chemistry as a function of salinity and temperature, J. Geophys. Res.-Atmos., 114, D20305, https://doi.org/10.1029/2009JD012481, 2009.

O’Dowd, C. D., Smith, M. H., Consterdine, I. E., and Lowe, J. A.: Marine aerosol, sea-salt, and the marine sulphur cycle: a short review, Atmos. Environ., 31, 73-80, https://doi.org/10.1016/S1352-2310(96)00106-9, 1997.

Perovich, D. K. and Richter-Menge, J. A.: Surface characteristics of lead ice, J. Geophys. Res.-Oceans, 99, 16341-16350, https://doi.org/10.1029/94JC01194, 1994.

Petit, J.-R., Jouzel, J., Raynaud, D., Barkov, N. I., Barnola, J.M., Basile, I., Bender, M., Chappellaz, J., Davis, M., and Delaygue, G.: Climate and atmospheric history of the past 420,000 years from the Vostok ice core, Antarctica, Nature, 399, 429436, 1999.

Quinn, P. K., Miller, T. L., Bates, T. S., Ogren, J. A., Andrews, E., and Shaw, G. E.: A 3-year record of simultaneously measured aerosol chemical and optical properties at Barrow, 
Alaska, J. Geophys. Res.-Atmos., 107, AAC 8-1-AAC 8-15, https://doi.org/10.1029/2001JD001248, 2002.

Reader, M. C. and McFarlane, N.: Sea-salt aerosol distribution during the Last Glacial Maximum and its implications for mineral dust, J. Geophys. Res.-Atmos., 108, 4253, https://doi.org/10.1029/2002JD002063, 2003.

Roscoe, H. K., Brooks, B., Jackson, A. V., Smith, M. H., Walker, S. J., Obbard, R. W., and Wolff, E. W.: Frost flowers in the laboratory: Growth, characteristics, aerosol, and the underlying sea ice, J. Geophys. Res.-Atmos., 116, D12301, https://doi.org/10.1029/2010JD015144, 2011.

Röthlisberger, R., Mulvaney, R., Wolff, E. W., Hutterli, M. A., Bigler, M., de Angelis, M., Hansson, M. E., Steffensen, J. P., and Udisti, R.: Limited dechlorination of sea-salt aerosols during the last glacial period: Evidence from the European Project for Ice Coring in Antarctica (EPICA) Dome C ice core, J. Geophys. Res.-Atmos., 108, 4526, https://doi.org/10.1029/2003JD003604, 2003.

Savelyev, S. A., Gordon, M., Hanesiak, J., Papakyriakou, T., and Taylor, P. A.: Blowing snow studies in the Canadian Arctic Shelf Exchange Study, 2003-04, Hydrol. Process., 20, 817-827, https://doi.org/10.1002/hyp.6118, 2006.

Savoie, D. L., Arimoto, R., Keene, W. C., Prospero, J. M., Duce, R. A., and Galloway, J. N.: Marine biogenic and anthropogenic contributions to non-sea-salt sulfate in the marine boundary layer over the North Atlantic Ocean, J. Geophys. Res.-Atmos., 107, 4356, https://doi.org/10.1029/2001JD000970, 2002.

Shuman, C. A., Alley, R. B., Anandakrishnan, S., White, J. W. C., Grootes, P. M., and Stearns, C. R.: Temperature and accumulation at the Greenland Summit: Comparison of high-resolution isotope profiles and satellite passive microwave brightness temperature trends, J. Geophys. Res.-Atmos., 100, 9165-9177, https://doi.org/10.1029/95JD00560, 1995.

Shuman, C. A., Bromwich, D. H., Kipfstuhl, J., and Schwager, M.: Multiyear accumulation and temperature history near the North Greenland Ice Core Project site, north central Greenland, J. Geophys. Res.-Atmos., 106, 33853-33866, https://doi.org/10.1029/2001JD900197, 2001.

Sigl, M., McConnell, J. R., Layman, L., Maselli, O., McGwire, K., Pasteris, D., Dahl-Jensen, D., Steffensen, J. P., Vinther, B., Edwards, R., Mulvaney, R., and Kipfstuhl, S.: A new bipolar ice core record of volcanism from WAIS Divide and NEEM and implications for climate forcing of the last 2000 years, J. Geophys. Res.-Atmos., 118, 1151-1169, https://doi.org/10.1029/2012jd018603, 2013.
Steen-Larsen, H. C., Masson-Delmotte, V., Sjolte, J., Johnsen, S. J., Vinther, B. M., Bréon, F. M., Clausen, H. B., Dahl-Jensen, D., Falourd, S., Fettweis, X., Gallée, H., Jouzel, J., Kageyama, M., Lerche, H., Minster, B., Picard, G., Punge, H. J., Risi, C., Salas, D., Schwander, J., Steffen, K., Sveinbjörnsdóttir, A. E., Svensson, A., and White, J.: Understanding the climatic signal in the water stable isotope records from the NEEM shallow firn/ice cores in northwest Greenland, J. Geophys. Res., 116, D06108, https://doi.org/10.1029/2010jd014311, 2011.

Wagenbach, D., Ducroz, F., Mulvaney, R., Keck, L., Minikin, A., Legrand, M., Hall, J. S., and Wolff, E. W.: Sea-salt aerosol in coastal Antarctic regions. J. Geophys. Res.-Atmos., 103, 1096110974, https://doi.org/10.1029/97JD01804, 1998.

Wang, X., Zhang, L., and Moran, M. D.: Development of a new semi-empirical parameterization for below-cloud scavenging of size-resolved aerosol particles by both rain and snow, Geosci. Model Dev., 7, 799-819, https://doi.org/10.5194/gmd-7799-2014, 2014.

Xu, L., Russell, L. M., Somerville, R. C. J., and Quinn, P. K.: Frost flower aerosol effects on Arctic wintertime longwave cloud radiative forcing, J. Geophys. Res.-Atmos., 118, 2013JD020554, https://doi.org/10.1002/2013JD020554, 2013.

Yang, X., Pyle, J. A., and Cox, R. A.: Sea salt aerosol production and bromine release: Role of snow on sea ice, Geophys. Res. Lett., 35, L16815, https://doi.org/10.1029/2008GL034536, 2008.

Yang, X., Pyle, J. A., Cox, R. A., Theys, N., and Van Roozendael, M.: Snow-sourced bromine and its implications for polar tropospheric ozone, Atmos. Chem. Phys., 10, 7763-7773, https://doi.org/10.5194/acp-10-7763-2010, 2010.

Yang, X., Nedela, V., Runštuk, J., Ondrušková, G., Krausko, J., Vetráková, L'., and Heger, D.: Evaporating brine from frost flowers with electron microscopy and implications for atmospheric chemistry and sea-salt aerosol formation, Atmos. Chem. Phys., 17, 6291-6303, https://doi.org/10.5194/acp-176291-2017, 2017.

Zhang, L., Wang, X., Moran, M. D., and Feng, J.: Review and uncertainty assessment of size-resolved scavenging coefficient formulations for below-cloud snow scavenging of atmospheric aerosols, Atmos. Chem. Phys., 13, 10005-10025, https://doi.org/10.5194/acp-13-10005-2013, 2013.

Zwally, H. J., Schutz, B., Abdalati, W., Abshire, J., Bentley, C., Brenner, A., Bufton, J., Dezio, J., Hancock, D., Harding, D., Herring, T., Minster, B., Quinn, K., Palm, S., Spinhirne, J., and Thomas, R.: ICESat's laser measurements of polar ice, atmosphere, ocean, and land, J. Geodyn., 34, 405-445, https://doi.org/10.1016/S0264-3707(02)00042-X, 2002. 